\title{
STRUCTURAL ANALYSIS AND METAMORPHISM OF PALAEOPROTEROZOIC METAPELITES IN THE SEINÄJOKI- ILMAJOKI AREA, WESTERN FINLAND
}

\author{
HANNU MÄKITIE
}

MÄKITIE, HANNU 1999. Structural analysis and metamorphism of Palaeoproterozoic metapelites in the Seinäjoki-Ilmajoki area, western Finland. Bulletin of the Geological Society of Finland 71, Part 2, 305-328.

The Palaeoproterozoic Svecofennian bedrock of the Seinäjoki-Ilmajoki area, western Finland, is largely composed of porphyroblastic metapelites. In the area, the regional metamorphic grade increases towards the southwest. Over a distance of $15 \mathrm{~km}$, andalusite mica schists gradually grade into migmatitic garnetcordierite-sillimanite mica gneisses with a facies-series of the andalusite-sillimanite type. Five regional metamorphic zones are present: andalusite, sillimanite-muscovite, sillimanite-K-feldspar, cordierite-K-feldspar and garnet-cordierite-K-feldspar.

The primary layering $\left(\mathrm{S}_{0}\right)$ of the mica schists is deformed by an isoclinal fold phase $\left(\mathrm{F}_{2}\right)$, which is synchronous with the main metamorphic phase and the growth of micas. $S_{1}$ is very weak and subject to interpretation. The $S_{2}$ schistosity is deformed by intense late-metamorphic $F_{3}$ and $F_{3 b}$ folds, which have formed under slightly different metamorphic conditions: practically no metamorphic micas have grown parallel to axial planes while within $\mathrm{F}_{3 \mathrm{~b}}$ folds there are a few granitic veins parallel to these planes. The $\mathrm{F}_{3}$ and $\mathrm{F}_{3 \mathrm{~b}}$ folds probably belong to one phase. $S_{2}$ dominates in the mica schists while $S_{3}$ and $S_{3 b}$ dominate in the mica gneisses. The metapelites are also deformed by younger minor fold phases $\left(\mathrm{F}_{4}\right.$ and $\left.\mathrm{F}_{5}\right)$. A composite schistosity $\left(\mathrm{S}_{0} \pm \mathrm{S}_{1} \pm \mathrm{S}_{2} \pm \mathrm{S}_{3}\right.$ or $\left.\mathrm{S}_{3 \mathrm{~b}}\right)$ commonly occurs in the metapelites.

The peak of regional metamorphism has been associated with the intrusion of $1.89-1.88 \mathrm{Ga}$ old tonalite plutons. Geothermometric estimates for regional metamorphism are c. $730^{\circ} \mathrm{C}$ at an assumed pressure of $5 \mathrm{kbar}$. Neosomes in the high-grade mica gneisses occur as patches rather than as elongated, narrow veins. Garnet coexists with cordierite, but the minerals are rarely in equilibrium. Muscovitization and the formation of retrogressive andalusite did not occur in the high-grade mica gneisses, but there is minor kyanite indicating that the crust probably underwent near-isobaric cooling. The area of highest-grade regional metamorphic conditions contains a post-kinematic mangeritic quartz monzonite $(1.87 \mathrm{Ga})$, which has a narrow granulite-grade contact aureole. The chemical composition of biotites in the metapelites varies as a function of metamorphic zoning, but the chemical composition of metapelites remains mostly unchanged.

Key words: metapelite, structural analysis, metamorphism, zoning, chemical composition, electron probe data, P-T conditions, Paleoproterozoic, Svecofennian, Seinäjoki, Ilmajoki, Finland

Hannu Mäkitie: Geological Survey of Finland, P.O. Box 96, FIN-02151 Espoo, Finland.

E-mail: Hannu.Makitie@gsf.fi 


\section{INTRODUCTION}

The acceptance of the concept of a dynamic tectonic environment for regional metamorphism has led to the understanding that metamorphic rocks follow complex paths in P-T space, reflecting burial, heating and exhumation (e.g. Brown 1993). The tectonic setting for regional metamorphism is usually collision between continental elements and/or arcs that has resulted in substantial crustal thickening. The metamorphic style, cooling paths and relative age of deformation can vary within an orogenic belt. Therefore, in the research of ancient orogenic belts, regional studies of the structural succession and metamorphism of their exhumed crustal portions are necessary.

Metamorphically, the Palaeoproterozoic Svecofennian (1.9-1.8 Ga) crust of southern Finland is divided into two parts (Korja et al. 1994): (1) a northern part characterised by tonalite migmatites, in which the metasedimentary rocks are often psammitic, and (2) a southern part characterised by potassium granite migmatites, in which the metasedimentary rocks are usually metapelitic with excess aluminium in relation to alkalies and calcium. Both zones underwent intense metamorphism $\sim 1885 \mathrm{Ma}$ ago, but the southern part is also overprinted by a strong thermal pulse 1.86-1.81 $\mathrm{Ga}$ in age (Korsman et al. 1984, Ehlers et al. 1993). There is an E - W-trending tectonometamorphic discordance between these parts (Vaasjoki \& Sakko 1988). Several studies of deformation in relation to metamorphism in southern Finland have been published (e.g. Kilpeläinen 1988, 1998, Väisänen et al. 1994, Koistinen et al. 1996).

The Seinäjoki-Ilmajoki area, in western Finland, is situated north of the discordance, and mostly comprises high-temperature/low-pressure porphyroblastic metapelites (Neuvonen 1961, Mäkitie \& Lahti 1991). These rocks exhibit polyphase deformation and increase in regional metamorphic grade towards the mangeritic quartz monzonite stock of Luopa in the southwest (Fig. 1). The tectonometamorphic evolution of the Seinäjoki-Ilmajoki area is interesting because the area also contains various granitoids, rare-element pegmatites and $\mathrm{Sb}$-, $\mathrm{Sn}$ - and $\mathrm{Au}-$ mineralizations (e.g. Mäkitie \& Lahti 1991).

The purpose of this paper is to give an overview of the deformation and metamorphism of the area, which is based on a study of the metapelites.

\section{GEOLOGICAL SETTING}

The Seinäjoki-Ilmajoki area belongs to the Palaeoproterozoic accretionary arc complex of central and western Finland (1.90-1.87 Ga), which is a part of the Svecofennian domain (Korsman et al. 1997). The major part of the study area lies in the Svecofennian Pohjanmaa schist belt (also known as the Ostrobothnian schist belt), which includes orogenic granitoids (Fig. 1, see also Laitakari 1942). The main rock types of the study area are pelitic schists and gneisses (Mäkitie et al. 1991). In the northeast, the metapelites are finegrained andalusite mica schists, in the central part they are sillimanite-bearing mica gneisses, and the southwestern parts comprise migmatitic garnetcordierite-sillimanite mica gneisses. Mica schists and mica gneisses commonly have psammitic intercalations that in places dominate over the metapelites. Metavolcanic rocks are present in minor amounts.

In the northeast, near the town of Seinäjoki, pegmatite granites, rare-element pegmatites and Sb-mineralizations are common (Pääkkönen 1966, Borodaev et al. 1983, Oivanen 1983, Alviola 1989) (Fig. 1). Foliated tonalites (1882 $\pm 9 \mathrm{Ma})$ and granodiorites, which are associated with regional metamorphism, and which belong to the large Central Finland Granitoid Complex, occur in the southern part of the study area (Mäkitie \& Lahti 1991). In the south there are also granites and the post-kinematic, almost undeformed, porphyritic olivine-pyroxene quartz monzonite stock of Luopa

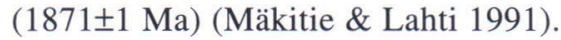

The regional metamorphic grade of the rocks increases to the southwest, from conditions of lowtemperature amphibolite facies to lower granulite facies with a facies-series of low-pressure intermediate type (Fig. 1). The highest-grade mineral assemblages are found in the overprinting contact aureole of the quartz monzonite of Luopa. The 


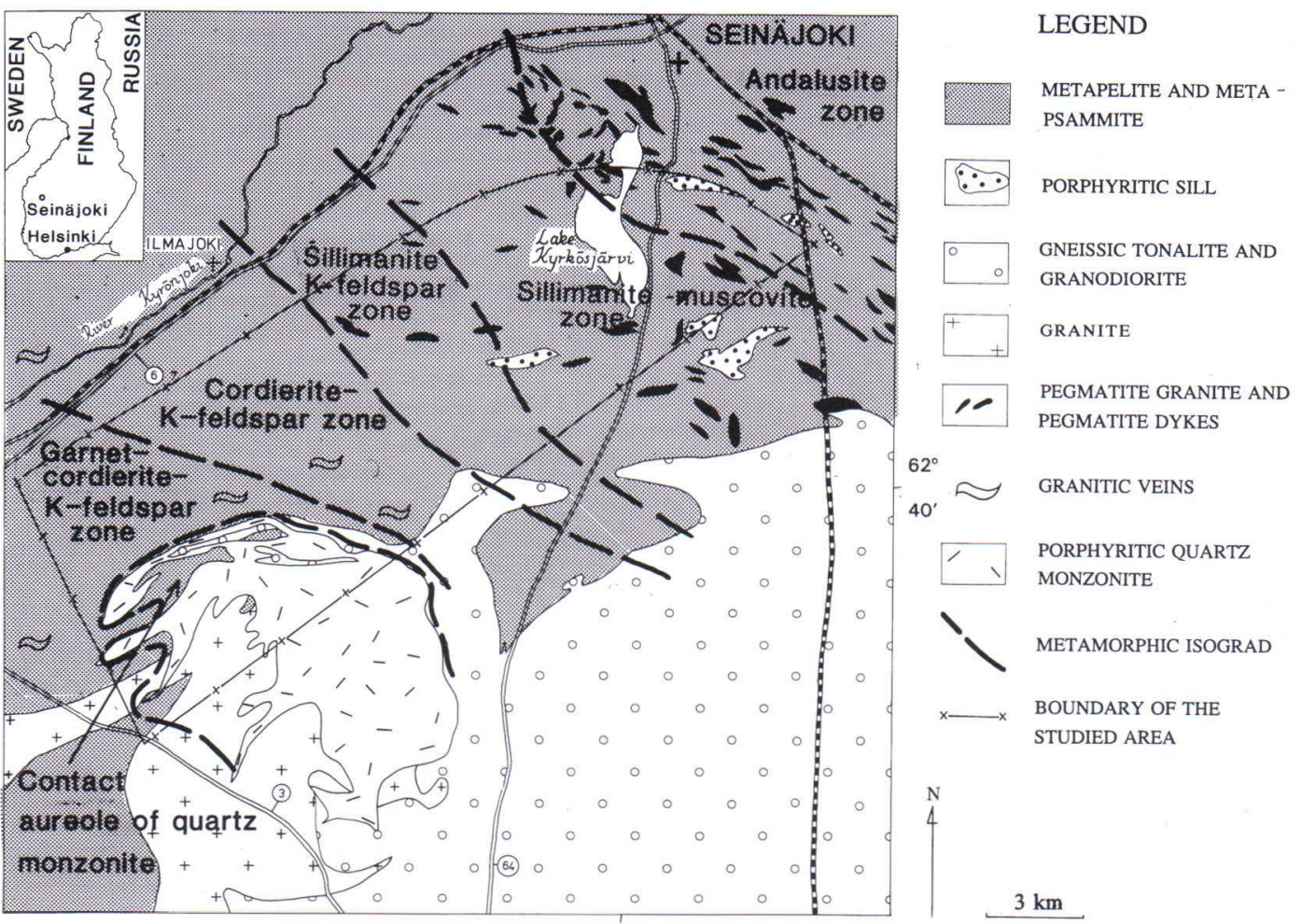

Fig. I. Geological map of the Seinäjoki-Ilmajoki area with metamorphic zones. Simplified after Lahti and Mäkitie (1990) and Mäkitie et al. (1991).

metapelites show polyphase folding. This highgrade metamorphic terrain and the quartz monzonite lie in an area that has a weak positive Bouger anomaly compared to the areas of mica schist (see Kiviniemi 1980).

\section{RESEARCH METHODS}

Polyphase fold-analysis followed principles set out in Hopgood and Bowes (1972), Koistinen (1981) and Kilpeläinen (1988). The relation of mineral growth to deformation phases was studied using precepts established by Zwart (1962) and Powell (1979). Temperature conditions were estimated with the geothermometers of Holdaway and Lee (1977) and Perchuk (1989).

Mineral analyses were made from polished thin sections using electron microprobes (JEOL-JCXA 733) at the University of Oulu and at the Geolog- ical Survey of Finland (GTK). The main elements as well as Rb, Sr, Ba, Zn, Zr, Cr, V, Th, U, Cs and $\mathrm{La}$ in whole rock analyses were determined by XRF (Y with OES) in the Chemistry Laboratories of the Rautaruukki Company and GTK.

The mineral abbreviations used are after Kretz (1983).

\section{STRUCTURAL SUCCESSION}

A structural map of the study area is shown in Fig. $2 \mathrm{a}$. The northern part of the area represents the southern limb of a regional east - west-trending antiform described by Pääkkönen (1966). A schematic, 3D-sketch of the foliations and the folded planar rock units of the northern and central study area is given in Fig. 2b. The primary layering $\left(\mathrm{S}_{0}\right)$ is best seen in the north, being increasingly obliterated towards the southwest because of the ris- 
ing metamorphic grade (Mäkitie 1990). Note that in the north, and near the hinge of the regional antiform, $S_{0}, S_{1}, S_{2}$ and $S_{3}$ have subparallel trends (Fig. 2b).

The dominant tight to isoclinal late-metamorphic folds $\left(\mathrm{F}_{3}\right.$ and $\left.\mathrm{F}_{3 \mathrm{~b}}\right)$ of the central and southern study area are disharmonic and in certain areas show uniformly dextral or uniformly sinistral features. The fold axes of $\mathrm{F}_{3}$ and $\mathrm{F}_{3 \mathrm{~b}}$ have similar trends (E-W) and are usually subparallel to the schistosity of the metapelites (Fig. 2a). The foliations usually dip steeply southwards. The central part contains a few individual folds with SE NW-trending axial planes that, in relation to metamorphism, are similar in style to the $\mathrm{F}_{3}$ and $\mathrm{F}_{3 \mathrm{~b}}$ folds. The foliated tonalites in the south also display a SE - NW-trending lineation. Younger deformation phases $\left(\mathrm{F}_{4}\right.$ and $\left.\mathrm{F}_{5}\right)$ are mostly seen in the mica schists. In the south, the Luopa quartz monzonite stock, which is post-kinematic in relation to the main deformation within the study area, deforms the surrounding mica gneisses and brecciates the granites.

\section{Primary layering and $D_{1}$ deformation}

The oldest planar structure is rare well-preserved primary layering $\left(\mathrm{S}_{0}\right)$, which occurs in andalusitestaurolite mica schists a few kilometres south of the town of Seinäjoki. This layering is composed of alternating thin beds of pelite $(0.2-10 \mathrm{~cm})$ and graded psammite $(1-50 \mathrm{~cm})$ (Fig. $3 \mathrm{a})$. The $\mathrm{S}_{0}$ layering is best preserved, when it is approximately perpendicular to the dominant schistosity $\left(\mathrm{S}_{2}\right)$ of the area. In places $S_{0}$ occurs as an indistinct trace discordant to $\mathrm{S}_{2}$. Elsewhere, it has been transposed parallel to the dominant schistosity.

The $\mathrm{S}_{0}$ layering contains some intrafolial folds interpreted as $F_{1}$. There is no mica growth parallel to $S_{0}$ or $S_{1}$, but elongated post- $D_{1}$ andalusite is parallel to $S_{0}$ and $S_{1}$ (Fig. 3a).

\section{$D_{2}$ deformation}

The $S_{0}$ and $S_{1}$ planes are deformed by a tight to isoclinal $\mathrm{F}_{2}$ fold phase, which has a well-developed synkinematic, metamorphic axial plane fo- liation with associated biotite and muscovite growth (Fig. 3b). The $\mathrm{S}_{2}$ schistosity forms the dominant foliation in the mica schists near the town of Seinäjoki. $S_{0}$ and $S_{1}$ are usually parallel to $S_{2}$ having been transposed on the limbs of isoclinal $F_{2}$ folds. These folds often have thickened hinges. Intersecting relations between $S_{0}$ and $S_{2}$ are seen in only a few outcrops (Fig. 3a). The $S_{2}$ schistosity is refracted where it intersects the pelitic and psammitic layers of $S_{0}$. Where $20-50 \mathrm{~cm}$ thick psammitic beds occur the angle of refraction can be as much as $40^{\circ}$. However, the outcrops clearly exhibiting $\mathrm{S}_{2}$ are mostly composed of thick units of homogeneous mica schists (see Fig. 4c). In places there are quartz veins parallel to $S_{2}$. Only right-handed $F_{2}$ folds are found.

\section{$D_{3}$ and $D_{3 b}$ deformations}

During the $\mathrm{D}_{3}$ deformation phase $\mathrm{S}_{0}, \mathrm{~S}_{1}$ and $\mathrm{S}_{2}$ planes and $\mathrm{F}_{2}$ fold axes were rotated to their present subvertical position (Fig. 2b). Associated late-metamorphic tight $\mathrm{F}_{3}$ folds tilted the $\mathrm{S}_{2}$ schistosity seen in the metapelites. The $\mathrm{F}_{3}$ folds (Fig. $3 \mathrm{c}$ ) are common in the sillimanite-muscovite-biotite gneisses $1-5 \mathrm{~km}$ to the south of the andalusite mica schists. The $\mathrm{F}_{3}$ folds vary in size and plunge relatively gently eastwards. The trend of the $S_{3}$ crenulation cleavage is almost parallel to $S_{2}$ (Fig. 3d). Parasitic structures are common and fold hinges are usually not thickened. Narrow pegmatitic veins in these sillimanite-muscovite-biotite gneisses are folded by $\mathrm{F}_{3}$ (Fig. 3c). Rarely mica segments occur in the $\mathrm{F}_{3}$ fold crest, parallel to the axial plane. Folds in certain areas are regularly either uniformly sinistral or uniformly dextral.

Further southwest $(15-25 \mathrm{~km})$ of the town of Seinäjoki, folds resembling $\mathrm{F}_{3}$ folds occur in the cordierite- and garnet-bearing mica gneisses (Fig. $3 e)$. The relation of these folds to metamorphic growth is similar to that in the aforementioned sillimanite-muscovite-biotite gneisses: biotite follows the shape of the fold hinges (Fig. 3f). There is no growth of garnet or cordierite in the axial plane of the folded palaeosomes. These late-metamorphic folds observed in the southwest are distinguished by the author as $F_{3 b}$, even though their 

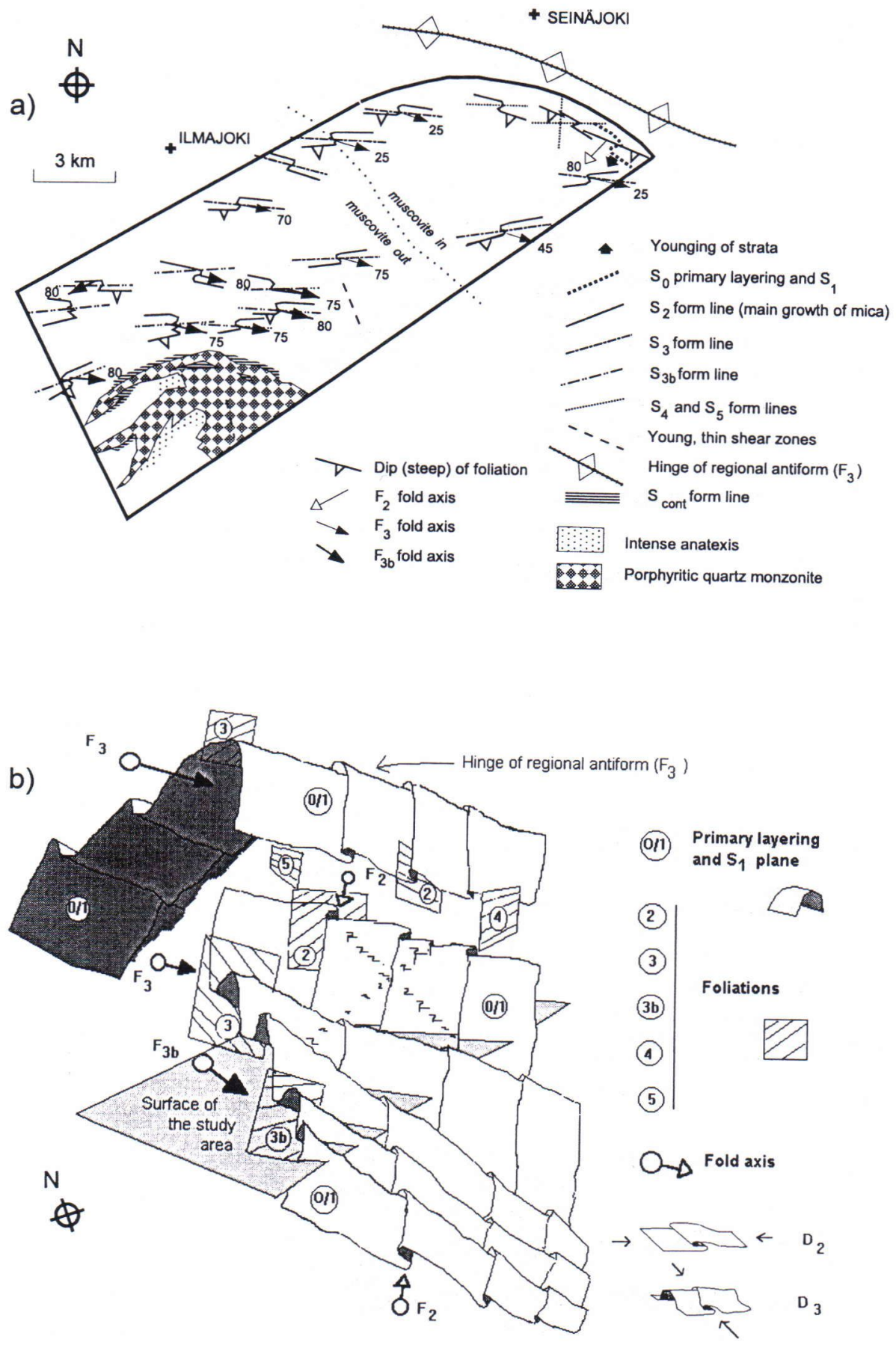

Fig. 2. a) Structural map of the Seinäjoki-Ilmajoki area with muscovite-out isograd. Note that the study area is bordered as in Fig. 1. b) 3D-sketch of the folded planar rock units in the northern and central part of the study area. Foliations are shown schematically by ruled planes. 

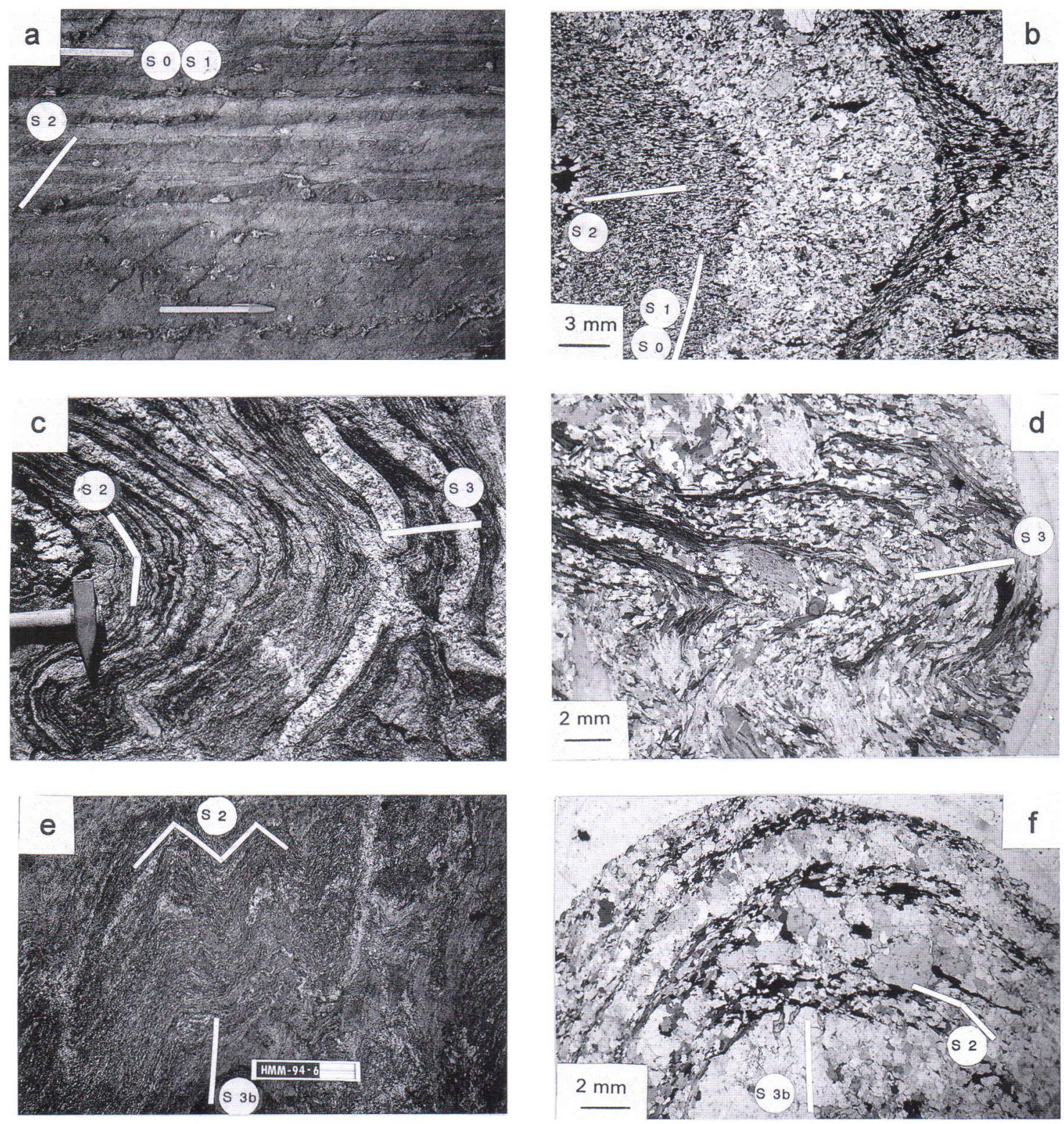

Fig. 3. Structures in metapelites of the Seinäjoki-Ilmajoki area. Coordinates are given as in the base coordination of Finnish maps. a) Andalusite-staurolite mica schist containing primary sedimentary layering $\left(S_{0}\right)$ and parallel weak $S_{1}$. The $S_{2}$ schistosity intersects $S_{0}$ and $S_{1}$. Elongated light-coloured knots are andalusite porphyroblasts mostly parallel to $S_{0}$ and $S_{1}$. Andalusite zone. Length of the pen is $15 \mathrm{~cm} . x=6960480, y=2443960 . b$ ) Photomicrograph of $F_{2}$ fold crest, which includes synkinematic metamorphic axial plane foliation $\left(S_{2}\right)$ with growth of biotite and muscovite. Mica schist from the andalusite zone. $x=6960480, y=2443950$. c) Late-metamorphic fold $\left(F_{3}\right)$ in muscovite-sillimanite (fibr.)-biotite gneiss. $S_{2}$ schistosity and narrow pegmatite veins are folded. Length of the blade of the hammer is $12 \mathrm{~cm}$. Sillimanite-muscovite zone. $x=6958680, y=2443670$. d) Photomicrograph of $F_{3}$ fold crest in muscovite-sillimanite (fibr.)-biotite gneiss. There is no mineral growth parallel to $S_{3}$. Sillimanite-muscovite zone. $x=6958690, y=2443680$. e) Folded $\left(F_{3 b}\right) K$-feldspar-garnet-cordierite-sillimanite mica gneiss containing granitic neosomes in the axial plane. Cordierite-K-feldspar zone. Length of code bar is 

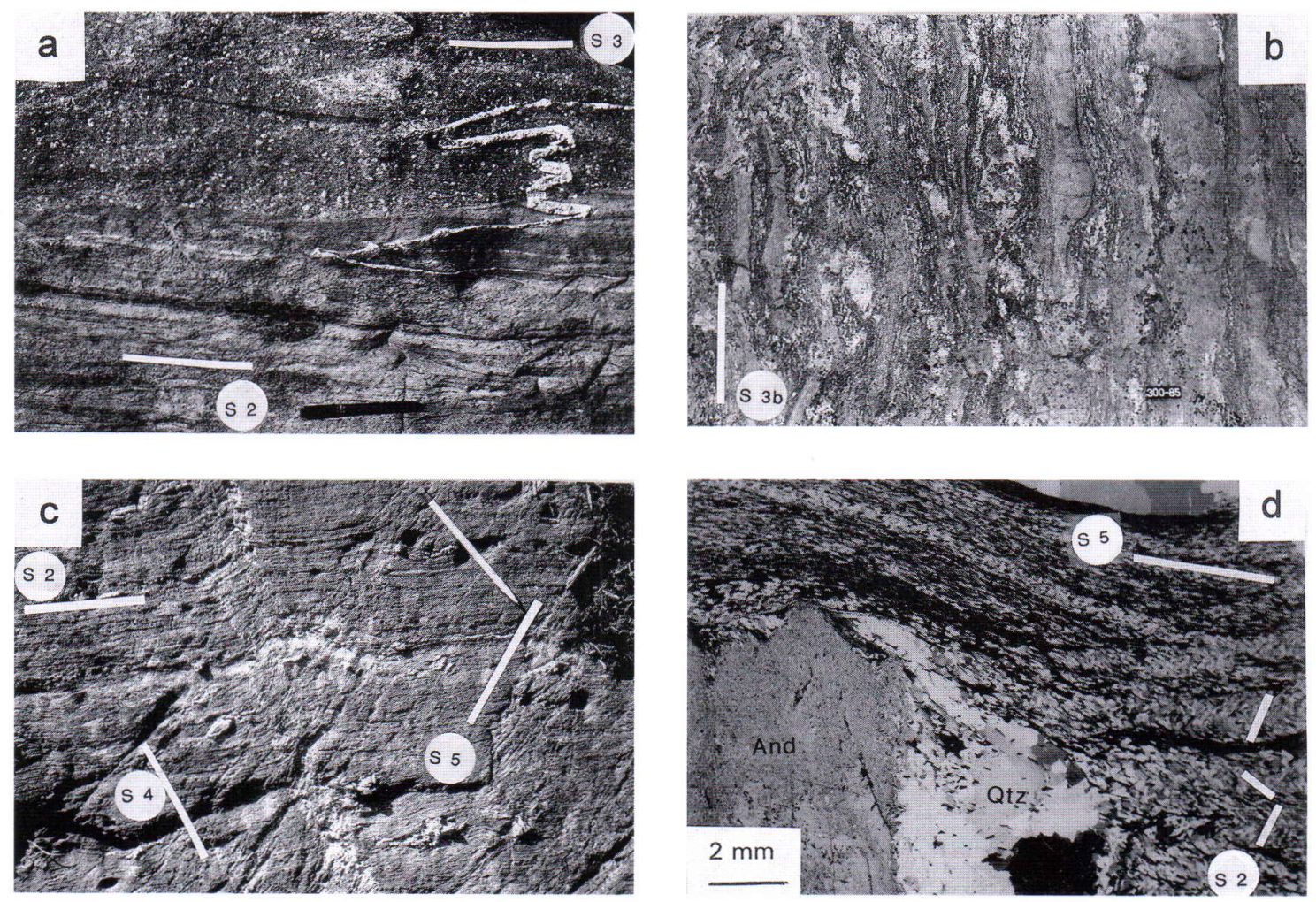

Fig. 4. Structures in metapelites of the Seinäjoki-Ilmajoki area. Coordinates are given as in the base coordination of the Finnish maps. a) Contact between plagioclase porphyrite sill (upper part of the figure) and mica schist shows a small angle with $S_{2}$. Both rocks and a narrow pegmatite are foliated $\left(S_{3}\right)$. The strikes of $S_{2}$ and $S_{3}$ are subparallel. Andalusite zone. Length of the black pen is $14 \mathrm{~cm} . x=6960780, y=2443720$. b) Typical garnetcordierite-sillimanite mica gneiss, in which $S_{0}, S_{1}, S_{2}$ and $S_{3 b}$ form a composite schistosity. Neosomes occur as patches rather than as elongated, narrow veins. Garnet-cordierite- $K$-feldspar zone. Length of code bar is $8 \mathrm{~cm}$. $x=6951390, y=2424410$. c) Typical andalusite mica schist of the Seinäjoki area. $D_{4}$ and $D_{5}$ have deformed $S_{2}$, which is parallel to $S_{0}$ and $S_{1}$. Knots are andalusite porphyroblasts. Length of the pen is $13 \mathrm{~cm}$. Andalusite zone. $x=6960780, y=2443750$. d) Photomicrograph of strongly crenulated $\left(S_{5}\right)$ mica schist, which contains a pre- $D_{5}$ andalusite (And) porphyroblast. Note the quartz $(Q t z)$ in pressure shadow of andalusite porphyroblast and that $S_{2}$ schistosity is folded. Andalusite zone. $x=6960470, y=2433940$.

fold axes are usually subparallel with those of $\mathrm{F}_{3}$ folds (see Fig. 2a).

Intersections of $S_{2}$ and $S_{3}$ are rare in the mica schists, which deform plastically. This is a reflec-

$15 \mathrm{~cm} . x=6951760, y=2427250 . f)$ Photomicrograph of $F_{3 b}$ fold crest of $K$-feldspar-garnet-cordierite-sillimanite mica gneiss. Note that metamorphic differentiation has formed microscopic layers and that the $S_{2}$ schistosity is folded. Cordierite-K-feldspar zone. $x=$ $6951780, y=2427240$. tion of the regional structure: the limb of a large antiform in which $\mathrm{S}_{2}$ and $\mathrm{S}_{3}$ are subparallel (Fig. 2b). However, one example of the relationship between $S_{2}$ and $S_{3}$ is shown in Fig. 4a, where $S_{2}$ in isoclinally folded $\left(\mathrm{F}_{2}\right)$ mica schist has a small angle with a plagioclase porphyrite sill, c. $1.89 \mathrm{Ga}$ old (Mäkitie \& Lahti 1991). Here, both rocks have been later deformed by $D_{3}$ forming $S_{3}$ foliation that is, in practice, parallel to $S_{2}$. A narrow pegmatite was intruded after $D_{2}$ and was folded by $F_{3}$ (Figs. 3c and 4a). There are also pegmatite boudins parallel to the dominant foliation in mica 
schist. These pegmatites have a similar tectonic position to the pegmatite in Fig. 4a; they are deformed by $D_{3}$ and due to the parallelism of $S_{3}$ and $\mathrm{S}_{2}$ the pegmatites are nearly conformable with the schists. However, some pegmatite dykes also cut the trend of the $S_{3}$ schistosity. Usually pegmatites are subconformable with the schists in the Seinäjoki area (Nurmela 1985).

No intersections between the $F_{3}$ and $F_{3 b}$ folds are found. Due to the subparallel trend of their fold axes (see Fig. 2a) and their relation to metamorphism (see Figs. $3 c-3 f$ ), the $F_{3}$ and $F_{3 b}$ folds probably belong to one regional-scale deformation phase. There are two main differences between $\mathrm{F}_{3}$ and $F_{3 b}$. Firstly, garnet- and cordierite-bearing granitic neosomes are more common in the axial planes of $\mathrm{F}_{3 \mathrm{~b}}$, indicating that there was a higher metamorphic temperature during folding in the southern part of study area. Secondly, the axes of $F_{3 b}$ are steeper than the axes of $F_{3}$ folds (Fig. 2a). The $F_{3 b}$ folds often have large $(0.2-2.0 \mathrm{~m})$ wavelengths and parasitic features. They are usually tight to isoclinal and disharmonic with, regionally, either a right-handed or a left-handed geometry; large parasitic fold structures can thus be determined. The psammitic beds in the area contain ptygmatic, narrow granitic veins. As a result of the formation of isoclinal $\mathrm{F}_{3}$ and $\mathrm{F}_{3 \mathrm{~b}}$ the foliation of the garnet-cordierite-sillimanite mica gneiss usually represents a composite schistosity (Fig. 4b).

\section{$D_{4}$ and $D_{5}$ deformations}

The structures formed by the $\mathrm{D}_{2}$ and $\mathrm{D}_{3}$ were locally deformed by young, in practice post-metamorphic fold phases $\left(\mathrm{F}_{4}\right.$ and $\left.\mathrm{F}_{5}\right)$, which occur as narrow bands in the andalusite mica schists and as gentle, disturbing folds in the sillimanite (fibr.)muscovite-biotite gneisses. These folds are kinks (Fig. 4c) but usually the hinge lines, especially as seen in microscopic scale, are curved. The density of the occurrence of these folds varies, and in some outcrops $D_{5}$ is so dominant that a $S_{5}$ schistosity, composed of mica-rich and mica-poor stripes, is formed (Fig. 4d). The east-west trending $\mathrm{S}_{5}$ schistosity is younger than the north-south trending $\mathrm{S}_{4}$ schistosity. The pegmatites were buck- le-folded during $\mathrm{D}_{5}$.

Some very narrow $(<2 \mathrm{~mm})$ late shear planes found in the garnet-cordierite-sillimanite mica gneisses intersect $S_{3}$ and $S_{3 b}$ with no associated mineral growth other than minor retrogressive chlorite after biotite. There are both brittle and ductile shears that usually trend NW-SE. Similar shears occur sporadically in the quartz monzonite of Luopa. The relationship of the shear zones to $\mathrm{D}_{4}$ and $\mathrm{D}_{5}$ is not clear.

\section{$D_{\text {cont }}$ deformation}

The emplacement of the post-kinematic quartz monzonite stock of Luopa deformed the surrounding mica gneisses resulting in a schistosity, here called the contact schistosity $\left(\mathrm{S}_{\text {cont }}\right)$. Previously folded and migmatized mica gneisses were strongly deformed and reoriented, and now they include the contact schistosity (Fig. 5a). In the mica gneisses, the $\mathrm{S}_{\text {cont }}$ schistosity occurs up to about $20 \mathrm{~m}$ from the contacts with the quartz monzonite. The trend of $S_{\text {cont }}$ follows that of the intrusive contacts and is strongest between wide (3-25 m), parallel apophysic dykes, which are most common in the northwestern part of the stock (see Lahti \& Mäkitie 1990, Mäkitie et al. 1991).

\section{METAMORPHISM}

The regional metamorphic zones of the study area are, from northeast to southwest, andalusite, sillimanite-muscovite, sillimanite-K-feldspar, cordierite-K-feldspar and garnet-cordierite-K-feldspar (Fig. 1). In addition, the overprinting granulitegrade contact aureole around the Luopa quartz monzonite occurs in the south.

The changes in mineral composition of metapelites in the metamorphic zones are shown in Table 1 . The average modal compositions and the average chemical compositions of the metapelites in the metamorphic zones are shown in Tables 2 and 3 . The relationships between the mineral assemblages and chemical whole rock compositions were studied using the AFM-diagrams of Thompson (1957) (Fig. 6). These diagrams also show the 

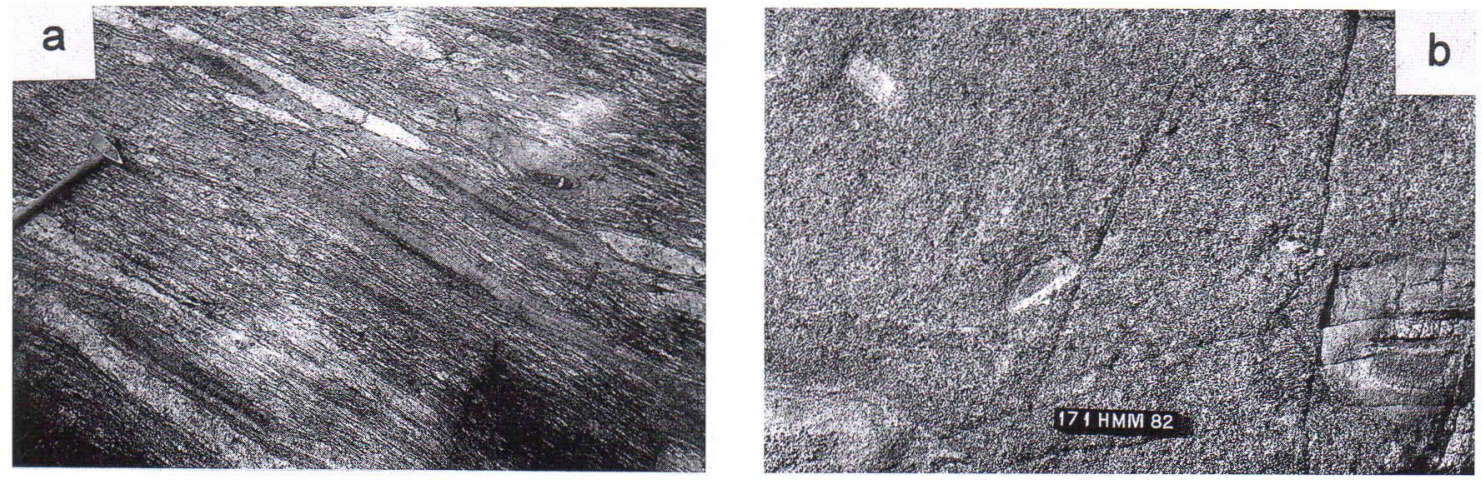

Fig. 5. Structures in metapelites of the contact aureole of the quartz monzonite stock of Luopa. Coordinates are given as in the base coordination of Finnish maps. a) Strongly deformed $\left(S_{\text {cont }}\right) K$-feldspar-garnet-cordierite-sillimanite mica gneiss $4 \mathrm{~m}$ from a wide quartz monzonite dyke. Contact aureole of Luopa quartz monzonite. Length of hammer is $50 \mathrm{~cm} . x=6949890, y=2525740$. b) Intensively homogenized $K$-feldspar-garnet-cordierite mica gneiss $4 \mathrm{~m}$ from a wide quartz monzonite dyke. Contact aureole of the Luopa quartz monzonite. Length of code bar is $12 \mathrm{~cm} . x=6945140, y=2424820$.

Table 1. Mineralogical changes in metapelites as a function of the metamorphic zoning in the Seinäjoki-Ilmajoki area.

\begin{tabular}{|c|c|c|c|c|c|c|}
\hline & $\begin{array}{l}\text { And } \\
\text { zone }\end{array}$ & $\begin{array}{l}\text { Sil-Ms } \\
\text { zone }\end{array}$ & $\begin{array}{l}\text { Sil-Kfs } \\
\text { zone }\end{array}$ & $\begin{array}{l}\text { Crd-Kfs } \\
\text { zone }\end{array}$ & $\begin{array}{l}\text { Grt-Crd- } \\
\text { Kfs zone }\end{array}$ & $\begin{array}{l}\text { Contact } \\
\text { aureole }\end{array}$ \\
\hline \multicolumn{7}{|l|}{ Quartz } \\
\hline \multicolumn{7}{|l|}{ Plagioclase } \\
\hline \multicolumn{7}{|l|}{ K-feldspar } \\
\hline \multicolumn{7}{|l|}{ Muscovite } \\
\hline \multicolumn{7}{|l|}{ Biotite } \\
\hline Tourmaline & \multicolumn{6}{|c|}{$-\ldots-1-1-1-1-1$} \\
\hline Staurolite & $\ldots$ & & & & & $\ldots$ \\
\hline Andalusite & $\longrightarrow$ & & & & & $\ldots$ \\
\hline \multicolumn{7}{|l|}{ Sillimanite } \\
\hline Kyanite & & & & & $\ldots$ & \\
\hline \multicolumn{7}{|l|}{ Cordierite } \\
\hline \multicolumn{7}{|l|}{ Garnet } \\
\hline Hercynite & & & & & & \\
\hline Orthopyroxene & & & & & & $-\ldots-1$ \\
\hline
\end{tabular}

positions of the chemical compositions of the studied biotites, cordierites and garnets (see Tables 4 and 5).

\section{Andalusite zone}

The metamorphic grade is lowest at the town of Seinäjoki, where andalusite mica schists and wellpreserved sedimentary structures are common.
Mica schists usually occur as thick (1-15 m), homogeneous units, in which $\mathrm{S}_{0}, \mathrm{~S}_{1}$ and $\mathrm{S}_{2}$ form a composite schistosity (Fig. 4c). Large, deformed porphyroblasts $(\varnothing 0.5-2.5 \mathrm{~cm})$ of andalusite are characteristic while this also occurs as grains elongated parallel to $S_{0}$ and $S_{1}$ (Fig. 3a). The mineral assemblage in these mica schists is muscovitequartz-plagioclase-biotite-andalusite. The chemical composition of the mica schists favours the 
Table 2. Average modal composition of metapelites as a function of metamorphic zoning in the Seinäjoki-Ilmajoki area. 'Others' include apatite, zircon, pinite, monazite etc. ${ }^{*}=$ includes also plagioclase, $+=$ occurs in small amounts, $(r)=$ has retrograde origin.

\begin{tabular}{|c|c|c|c|c|c|c|}
\hline & $\begin{array}{l}\text { And } \\
\text { zone }\end{array}$ & $\begin{array}{l}\text { Sil-Ms } \\
\text { zone }\end{array}$ & $\begin{array}{c}\text { Sil-Kfs } \\
\text { zone }\end{array}$ & $\begin{array}{c}\text { Crd-Kfs } \\
\text { zone }\end{array}$ & $\begin{array}{l}\text { Grt-Crd- } \\
\text { Kfs zone }\end{array}$ & $\begin{array}{l}\text { Contact } \\
\text { aureole }\end{array}$ \\
\hline Quartz & $47 *$ & 28 & 27 & 23 & 29 & 28 \\
\hline Plagioclase & n.d. & 17 & 16 & 11 & 11 & 13 \\
\hline K-feldspar & - & + & 8 & 15 & 15 & 14 \\
\hline Muscovite & 15 & 5 & 3 & - & - & - \\
\hline Biotite & 36 & 43 & 40 & 35 & 24 & 23 \\
\hline Tourmaline & + & + & - & - & - & - \\
\hline Staurolite & + & - & - & - & - & $+(\mathrm{r})$ \\
\hline Andalusite & 1 & - & - & - & - & $+(\mathrm{r})$ \\
\hline Sillimanite & - & 4 & 4 & 5 & 4 & 1 \\
\hline Kyanite & - & - & - & - & $+(\mathrm{r})$ & - \\
\hline Cordierite & - & - & - & 7 & 6 & 9 \\
\hline Garnet & + & - & + & 3 & 10 & 10 \\
\hline Hercynite & - & - & - & - & - & + \\
\hline Orthopyroxene & _- & _- & _- & _- & - & + \\
\hline Opaques & + & 1 & 1 & 1 & 1 & 1 \\
\hline Others & + & + & + & + & + & + \\
\hline Total & 100 & 100 & 100 & 100 & 100 & 100 \\
\hline
\end{tabular}

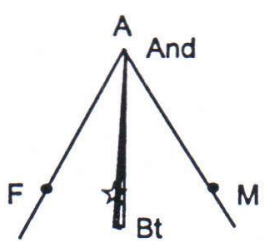

Andalusite zone

a

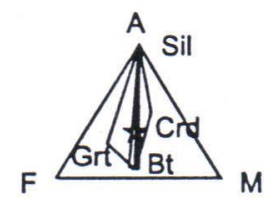

Cordierite-K-feldspar zone

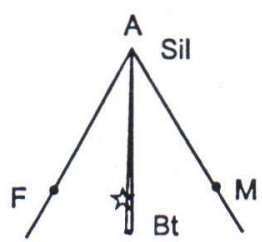

Sillimanite-muscovite zone

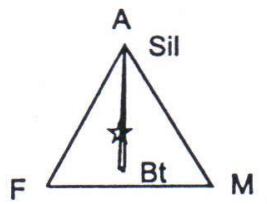

Sillimanite-K-feldspar zone
$c$
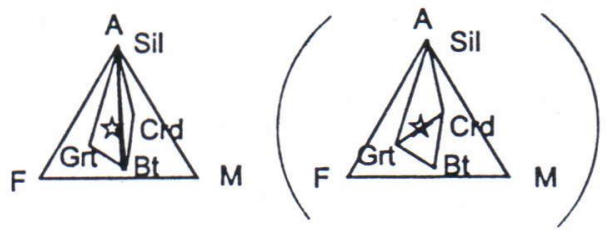

Gamet-cordieriteK-feldspar zone

Cordierite-garnetK-feldspar zone $f$

\section{= chemical composition of the metapelites}

Fig. 6. AFM-diagrams (a-f) (Thompson 1957) for the regional metamorphic zones of the Seinäjoki-Ilmajoki area. The average chemical composition of the metapelites studied and their minerals are shown in the diagrams (see Tables 3-5). The garnet-cordierite- $K$-feldspar zone includes two different AFM-diagrams ( $e, f)$; the assemblage in parenthesis is rare. 
formation of andalusite (see Fig. 6a). The accessory minerals in the mica schists are tourmaline, apatite, zircon, opaque minerals and retrogressive chlorite. In outcrops where sedimentary bedding is best preserved, there are also a few garnets and staurolites. Pegmatite granites, barren pegmatites and rare-element pegmatites occur commonly in the mica schists.

The andalusite is relatively rich in opaque inclusions, possibly indicating that the mineral is formed from Fe-Mg silicates such as staurolite or chlorite. Staurolite is surrounded by progressive coarse-grained muscovite and partly by biotite. Garnet is subhedral, with inclusion-free rims, and is in contact with andalusite. The abundant andalusite in the mica schists indicates that the pressure during metamorphism was low, some 13 kbar.

\section{Sillimanite-muscovite zone}

The metapelites of this zone are coarse-grained mica gneisses (Figs. 3c and 3d) having the mineral assemblage sillimanite (fibr.)-muscovite-biotite-plagioclase-quartz (Table 2). The accessory minerals include tourmaline, zircon, opaque minerals and apatite. Opaque minerals, mostly magnetite, occur with relatively high modes $(0.5-$ $1.5 \%$ ), often as inclusions in biotite. The grain size of micas increases to the southwest. Muscovite usually occurs as individual coarse-grained (1-8 mm), discordant porphyroblasts and consequently these gneisses often appear speckled. Psammitic metasediments and narrow pegmatite dykes are common within this zone (see Fig. 3c). Compared to within the andalusite zone, pegmatite granites occur in smaller volumes.

The sillimanite occurs as fibrolitic needles within coarse-grained muscovite and plagioclase and in small quartz inclusions in poikiloblasts of muscovite. Some sillimanite is also detected in quartz and plagioclase near the boundaries of muscovite. In addition, fibrolitic sillimanite forms clusters $(\varnothing 0.2-1.5 \mathrm{~cm})$ with quartz and muscovite (Fig. 7a).

Muscovite-sillimanite-biotite gneisses are not unusual (e.g. Evans \& Guidotti 1966, Tracy 1978) and many topological facies types involving muscovite have been discussed (e.g. Thompson \& Thompson 1976). In the study area, sillimanite has probably formed in the muscovite-bearing gneisses by reaction (1) (below; for references to the reactions presented here, see Spear 1993). Some of the sillimanite may also have formed by base cation leaching reaction described by Vernon (1979). In places muscovite containing fibrolitic needles of sillimanite replaces deformed biotites. At such localities there is also contemporaneous magnetite.

$$
\begin{aligned}
& \text { (1) Sodic } \mathrm{Ms}+\mathrm{Qtz}=\mathrm{K} \text {-richer } \mathrm{Ms}+\mathrm{Ab} \\
& +\mathrm{Sil}+\mathrm{H}_{2} \mathrm{O} \\
& \text { (2) } \mathrm{Ab}+\mathrm{Ms}+\mathrm{Qtz}=\mathrm{Kfs}+\mathrm{Sil}+\mathrm{H}_{2} \mathrm{O} \\
& \text { (3) } \mathrm{Ms}+\mathrm{Qtz}=\mathrm{Kfs}+\mathrm{Sil}+\mathrm{H}_{2} \mathrm{O} \text { or melt }
\end{aligned}
$$

The common occurrence of coexisting muscovite and sillimanite without K-feldspar in the sillimanite-muscovite zone indicates that the P-T conditions of metamorphism were slightly above the intersection of the andalusite-sillimanite inversion line and of dehydration reactions (2) and (3). The chemical composition of the metapelites plots partly on the tieline between sillimanite and biotite on the AFM-diagram shown in Fig. 6 b.

\section{Sillimanite-K-feldspar zone}

The mica gneisses of the sillimanite-K-feldspar zone contain two separate mineral assemblages, named (I) and (II):

(I) K-feldspar-muscovite-biotite-plagioclasequartz-magnetite-tourmaline \pm sillimanite

(II) K-feldspar-sillimanite-biotite-plagioclasequartz-magnetite \pm garnet

The different mineral assemblages reflect small variations in metamorphic grade and/or whole rock chemistry. Assemblage (I) mainly occurs in the northeastern part of the zone and assemblage (II) mostly in the southwestern part. Thus, the sillimanite-K-feldspar zone contains a 'muscovite out' -isograd, located approximately in the mid- 

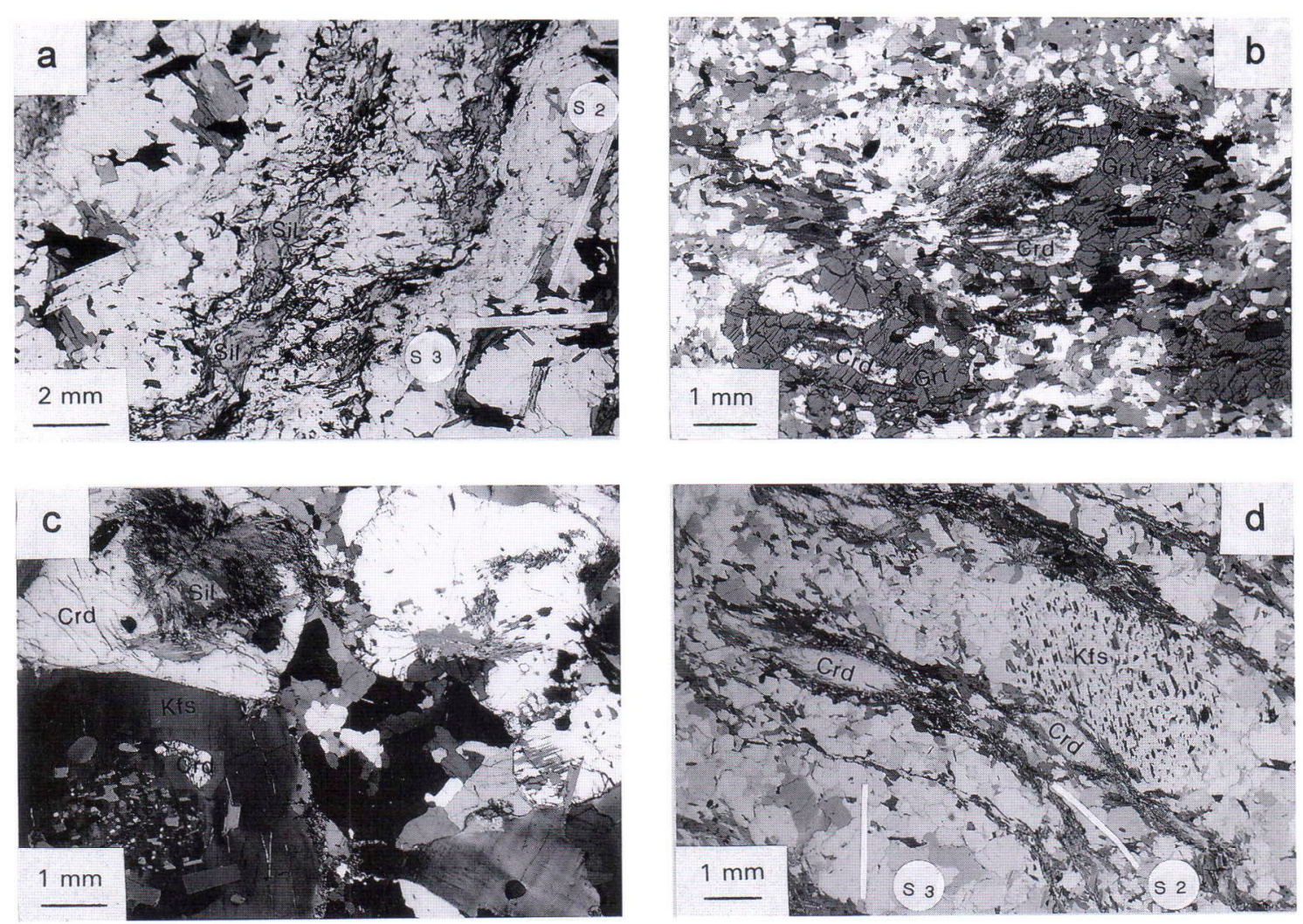

Fig. 7. Structures in metapelites of the Seinäjoki-Ilmajoki area. Coordinates are given as in the base coordination of the Finnish maps. a) Part of the crest of a large $F_{3}$ fold, with a cluster composed of sillimanite (fibr.), muscovite and quartz. Sillimanite (Sil) is folded, but some of it is segmented in the axial plane of $F_{3}$. Sillimanitemuscovite zone. $x=6961050, y=2436900$. b) Cordierites $(\mathrm{Crd})$ are rimmed by garnet (Grt). Garnet-cordierite$K$-feldspar zone. $x=6951940, y=2428490$. c) A large cordierite $(\mathrm{Crd})$ grain is partly decomposed to biotite, quartz and sillimanite (Sil) because of retrogressive metamorphism. $K$-feldspar $(K f s)$ is crystallized around older K-feldspar and includes cordierite $(\mathrm{Crd})$ and biotite. Garnet-cordierite-K-feldspar zone. $x=6949860, y=$ 2423240. d) Cordierite $(\mathrm{Crd})$ is crystallized parallel to $S_{2}$, but a porphyroblast of $K$-feldspar (Kfs) is rotated during the $F_{3 b}$ folding. Metamorphic differentiation has formed microscopic layers. Cordierite- $K$-feldspar zone. $x=6949850, y=2423230$.

dle of the zone. Both zones contain rare anatectic granite patches.

The mica gneisses of assemblage (I) are slightly coarser in grain size and show a more pronounced schistosity compared to the gneisses of assemblage (II). However, the grain size of sillimanite is usually coarser in the latter assemblage. Most of the $\mathrm{K}$-feldspar in the sillimanite-K-feldspar zone forms as a product of the common dehydration reactions (2) and (3). Changes in the mineral abundances in the rocks agree with these reactions (see Table 2).
Evans and Guidotti (1966) noted in their detailed study of reaction (2) in Maine, USA, that the muscovite-K-feldspar-sillimanite assemblage can occur over a distance of several kilometres from the reaction line (2). Moreover, the tieline switching reaction (3) usually occurs over a relatively wide range of temperatures (Evans \& Guidotti 1966), partly due to the $\mathrm{CaO}$ content of plagioclase (e.g. Tracy 1978). The 'muscovite out' -isograd in the Ilmajoki area is an irregular line, probably partly due to the gentle plunge of the $\mathrm{F}_{3}$ fold axis (Fig. 2a). In the study area the isograd 
occurs in a zone two kilometres wide.

In the mica gneisses with assemblage (I), biotite both rims K-feldspar porphyroblasts and occurs as inclusions in K-feldspar. Muscovite is coarsegrained $(0.3-1 \mathrm{~cm})$, intergrown with biotite and typically contains fibrolitic sillimanite. There are some sillimanite needles in quartz and plagioclase inclusions in muscovite poikiloblasts. Fibrolitic sillimanite also occurs in biotite. The muscovite contains clusters of an unidentified, fibrolitic aggregate. Clusters composed of fibrolitic sillimanite, quartz and muscovite are locally common. Apatite is often relatively coarse-grained. Mica gneisses containing muscovite, sillimanite and $\mathrm{K}$-feldspar indicate the P-T conditions of discontinuous reaction (3).

Tourmaline is present in the metapelites of assemblage (I). Boron decreases the solidus temperature of a granitic melt, and locally high amounts of boron possibly had a role in forming the present $\mathrm{K}$-feldspar-bearing mineral assemblage (interstitial K-feldspar being crystallized from a melt?). Thus, the high boron content may partly explain the varying position of the 'K-feldspar in' -isograd in the muscovite-bearing gneisses.

The metapelites of assemblage (II) differ from those of assemblage (I) in their clearer plagioclase twinning, in their lower amounts of opaque minerals and sulphur, and in an absence of muscovite and tourmaline. Sillimanite often occurs as individual clusters with a size of $1-3 \mathrm{~mm}$. There are irregular porphyroblasts (1-2 $\mathrm{mm}$ ) of K-feldspar that often contain the $\mathrm{S}_{2}$ schistosity. There are less pegmatite granites than in the andalusite and sillimanite-muscovite zones, in a decreasing amount to the southwest. On an AFM-diagram, the chemical composition of the metapelites partly plots on the between K-feldspar and sillimanite tieline (Fig. 6c).

\section{Cordierite-K-feldspar zone}

The metapelites in the cordierite-K-feldspar zone occur usually between psammitic layers as homogeneous rocks with no intensely developed schistosity. From the middle part of the zone towards the southwest, metamorphic differentiation (seg- regation) is common (Fig. 3f). The mica gneisses of the zone have the mineral assemblage cordierite, K-feldspar, biotite, sillimanite, plagioclase, quartz with or without garnet. Garnet is absent near the sillimanite-K-feldspar zone. The garnetcordierite ratio increases to the southwest. Garnet and cordierite are never in grain contact. Magnetite is an accessory mineral.

Cordierite and most of the K-feldspar form in the continuous reaction (4). This decomposition reaction of biotite is evident from comparison of the modes of the sillimanite-K-feldspar zone and cordierite-K-feldspar zone (see Table 2). Some garnets have crystallized in the relatively Fe-rich parts of metapelites by reaction (5), but, usually, the relatively high $\mathrm{MgO}-\mathrm{FeO}_{\text {tot }}$ ratio in metapelites has favoured the formation of cordierite (see Fig. $6 \mathrm{~d})$. The average chemical composition of the metapelites does not clearly plot in the field of SilBt-Crd on the AFM-diagram, as it should if reaction (4) was to dominate (Fig. 6d). However, the position of the average whole rock composition at the Sil-Bt tieline corresponds to the abundant sillimanite and biotite in the cordierite-K-feldspar zone.

$$
\begin{aligned}
& \text { (4) } \mathrm{Bt}+\mathrm{Sil}+\mathrm{Qtz}=\mathrm{Crd}+\mathrm{Kfs}+\mathrm{H}_{2} \mathrm{O} \text { or melt } \\
& \text { (5) } \mathrm{Bt}+\mathrm{Sil}+\mathrm{Qtz}=\mathrm{Grt}+\mathrm{Kfs}+\mathrm{H}_{2} \mathrm{O} \text { or melt }
\end{aligned}
$$

Cordierite porphyroblasts near the sillimanite$\mathrm{K}$-feldspar zone are partly zoned: there is a core containing fibrolitic sillimanite and a rim containing biotite inclusions. K-feldspar porphyroblasts contain biotite, quartz and plagioclase inclusions. In the northeastern part of the zone, sillimanite occurs as individual, medium-grained grains forming clusters, but elsewhere individual sillimanite is usually intergrown with biotite. In the zone, anatectic granitic patches and veins occur in small amounts while pegmatite granite intrusions and pegmatite dykes are rare.

\section{Garnet-cordierite-K-feldspar zone}

The metapelites of this zone are migmatitic garnet-cordierite-sillimanite mica gneisses (Fig. 4b). 
Garnet coexists with cordierite (coexistence is an index of the zone) but mostly equilibrated mineral-pairs are rare. Therefore, the isograd between the cordierite-K-feldspar zone and the garnet-cordierite-K-feldspar zone does not indicate the P-T conditions of equilibrated garnet and cordierite.

Melting occured in the mica gneisses of this zone. The anatectic material appears as patches, rarely as narrow, elongated veins, and includes garnet and cordierite (Figs. $3 \mathrm{e}$ and $4 \mathrm{~b}$ ). Between psammitic intercalations, these gneisses are often composed of a relatively homogeneous, mediumto coarse-grained garnet-cordierite-K-feldspar-plagioclase-quartz-sillimanite-biotite rock without an intense foliation, but with some indistinct patches of anatectic material.

The mode of garnet and cordierite is high, together about $15 \%$ (Table 2). The high content of biotite and sillimanite in these gneisses indicates that the temperature was not high enough to cause intense dehydration and melting by reaction (6). In places, garnet surrounds cordierite (Fig. 7b), particularly at the boundary between the cordierite-K-feldspar zone and the garnet-cordierite-Kfeldspar zone. This texture, which resembles corona structure, may be interpreted in at least two different ways. Either garnet has formed from cordierite during increasing pressure in a reaction such as (7), or during increasing temperature by reaction (8). In coronas, the grain contacts between garnet and cordierite are usually sharp without intergrowths of sillimanite and quartz.

$$
\begin{aligned}
& \mathrm{Bt}+\mathrm{Sil}+\mathrm{Qtz}=\mathrm{Grt}+\mathrm{Crd}+\mathrm{Kfs}+\text { melt } \\
& \mathrm{Crd}=\mathrm{Grt}+\mathrm{Sil}+\mathrm{Qtz}+\text { melt } \\
& \mathrm{Bt}+\mathrm{Crd}+\mathrm{Qtz}=\mathrm{Grt}+\mathrm{Kfs}+\text { melt }
\end{aligned}
$$

The Mg-Fe ratio of biotite is higher in the garnet-cordierite-K-feldspar zone compared to that in the cordierite-K-feldspar zone causing a shift of the tieline between biotite and sillimanite on the AFM-diagram to the right (see Table 4 and Figs. $6 \mathrm{~d}$ and $6 \mathrm{e})$. This partly explains why in reactions (4) and (5) more garnet forms than cordierite. Due to the rarity of clearly equilibrated garnet-cordierite pairs, the AFM-diagram showing a tieline between garnet and cordierite is in parenthesis in Fig. 6f.

Thin layers rich in either ferromagnesian minerals or felsic minerals formed by microscopic metamorphic differentiation are common (see Fig. 3f). The cores of cordierite porphyroblasts often include fibrolitic sillimanite, which is probably a relict phase. However, some cordierites also include relatively coarse-grained sillimanites and biotites formed during decomposition of the cordierite (Fig. 7c). Sillimanite is often intergrown with biotite and in places sillimanite surrounds magnetite. K-feldspar porphyroblasts in the palaeosome of gneisses have a grain size of 0.2 $1.5 \mathrm{~cm}$, but the minerals do not usually contain garnet or cordierite inclusions. Apatite is often relatively coarse-grained.

The rocks also include some fine-grained kyanite. Reaction (6) has a steep positive dp/dTslope. Thus, if the metamorphic pressure is relatively high (c. $5 \mathrm{kbar}$ ), initiation of this reaction requires temperatures over $700{ }^{\circ} \mathrm{C}$ (see Holdaway \& Lee 1977).

Metamorphic orthopyroxene has crystallized in intermediate metavolcanic rocks in the garnetcordierite-K-feldspar zone. In the study area the 'orthopyroxene in' -isograd is slightly south of the boundary between the garnet-cordierite-K-feldspar zone and the cordierite-K-feldspar zone. Locally the orthopyroxene is partly decomposed to clinopyroxene. This orthopyroxene does not necessarily indicate very high metamorphic temperatures because, for example, experimental studies have shown that in quartz-saturated mafic rocks, compared to quartz-undersaturated mafic rocks, the metamorphic temperature of the first appearance of orthopyroxene is lower (e.g. Spear 1981).

\section{Contact aureole}

The intrusion of the quartz monzonite stock of Luopa led to the formation of a narrow (c. $25 \mathrm{~m}$ ) upper amphibolite grade to granulite grade contact metamorphic aureole (Fig. 1) (Mäkitie \& Lahti 1991). This thermal event overprints the effects 
of regional metamorphism. The contact metamorphic rocks display the effects of intense anatexis (Fig. 5b). In places there are equilibrated garnetcordierite pairs, garnet-orthopyroxene pairs and coronas composed of hercynite, sillimanite and cordierite. Retrogressive andalusite and staurolite have formed during cooling. The contact aureole has a slightly higher cordierite-garnet ratio than the surrounding regionally metamorphic terrain indicating (with the retrogressive andalusite) lower pressures than in regional metamorphism.

\section{Retrograde reactions}

The most characteristic feature of retrograde metamorphism in the studied regional metamorphic terrain is the absence of retrogressive andalusite and muscovitization. Retrogressive, very finegrained muscovite occurs only rarely in cracks in porphyroblasts and, in the garnet-cordierite-Kfeldspar zone, in few grain contacts between cordierite and $\mathrm{K}$-feldspar.

The andalusite of mica schists is partly decomposed to a light-coloured, unidentified aggregate. Retrograde chlorite occurs in some thin shear zones and rarely in decomposed garnets, often with biotite, in the high-grade mica gneisses.

In the garnet-cordierite-K-feldspar zone, parts of the relatively coarse-grained cordierites and garnets are decomposed to quartz, clusters of sillimanite and light green biotite indicating that reactions (4) and (5) proceeded also from right to left (Fig. 7c). The examples mentioned above usually contain polycrystalline coarse-grained K-feldspar and relatively abundant apatite (Fig. 7c). Hornblende replaces orthopyroxene in the intermediate metavolcanic rocks of the garnet-cordierite-K-feldspar zone.

The regional metamorphic garnet-cordierite-sillimanite mica gneisses contain fine-grained rare kyanite (identified by X-ray methods). It is noteworthy that progressive kyanite schists are not known up to $250 \mathrm{~km}$ from the town of Seinäjoki. The kyanite at Ilmajoki probably formed during crustal cooling.

\section{MINERAL GROWTH IN RELATION TO DEFORMATION}

\section{Biotite and muscovite}

Most of the biotite and muscovite have grown synkinematically with $\mathrm{F}_{2}$ folding resulting in the formation of the dominant axial plane foliation $\left(\mathrm{S}_{2}\right)$ in the northern study area, particularly in the mica schists (see Figs. $3 \mathrm{~b}$ and $4 \mathrm{c}$ ). The mica gneisses include coarse-grained progressive muscovites that overgrow the $S_{2}$ schistosity with slight discordancy indicating that few muscovites crystallized after $\mathrm{F}_{2}$.

Very rarely, there are two intersecting (angle $10^{\circ}$ ) trends in the andalusite mica schists. One is $\mathrm{S}_{0} / \mathrm{S}_{1}$, which indicates the position of the limb of a tight to isoclinal $\mathrm{F}_{2}$ fold, and the other is the axial plane schistosity $\left(\mathrm{S}_{2}\right)$ of $\mathrm{F}_{2}$. The synkinematic $\left(\mathrm{D}_{2}\right)$ micas are folded by $\mathrm{F}_{3}$ or $\mathrm{F}_{3 \mathrm{~b}}$ as well as by $\mathrm{F}_{4}$ and $\mathrm{F}_{5}$. All crenulate the mica-rich foliation (e.g. Figs. $3 \mathrm{~d}$ and $4 \mathrm{c}$ ). In a few places, coarse-grained biotites, segmented in the axial plane of $\mathrm{F}_{3}$ and $\mathrm{F}_{3 \mathrm{~b}}$, occur in mica gneisses that have been metamorphosed on higher temperature side of the first sillimanite isograd.

\section{Andalusite and sillimanite}

Andalusite porphyroblasts in the mica schists predate $\mathrm{F}_{5}$ (Fig. 4d). In outcrops with well-preserved sedimentary layering there are elongated andalusites parallel to $S_{0}$ and $S_{1}$, which follow the curvature of $\mathrm{F}_{2}$ folds (Fig. 3a). These andalusites have crystallized within thin layers parallel to $S_{0} / S_{1}$ as the result of their suitable, aluminium-rich chemical composition. Further, a later phase of andalusite including opaques formed more clearly overprinting $S_{2}$ at the crystal ends of earlier andalusites. Finally, retrogressive andalusite formed in the contact aureole of the Luopa quartz monzonite stock.

$\mathrm{F}_{3}$ folds deform elongated clusters of sillimanite parallel to $\mathrm{S}_{2}$ schistosity. In some large $\mathrm{F}_{3}$ folds, because of the stress, part of the sillimanite needles are segmented parallel to the axial planes (Fig. 7a). In the garnet-cordierite mica gneisses, 
Table 3. Average chemical composition of metapelites as a function of metamorphic zoning in the Seinäjoki-Ilmajoki area. $n=$ amount of analyses.

\begin{tabular}{|c|c|c|c|c|c|c|}
\hline & $\begin{array}{l}\text { And } \\
\text { zone } \\
(\mathrm{n}=8)\end{array}$ & $\begin{array}{l}\text { Sil-Ms } \\
\text { zone } \\
(\mathrm{n}=7)\end{array}$ & $\begin{array}{l}\text { Sil-Kfs } \\
\text { zone } \\
(\mathrm{n}=4)\end{array}$ & $\begin{array}{l}\text { Crd-Kfs } \\
\text { zone } \\
(\mathrm{n}=10)\end{array}$ & $\begin{array}{l}\text { Grt-Crd- } \\
\text { Kfs zone } \\
(\mathrm{n}=10)\end{array}$ & $\begin{array}{l}\text { Contact } \\
\text { aureole } \\
(\mathrm{n}=5)\end{array}$ \\
\hline $\mathrm{SiO}_{2}$ (wt-\%) & 64.70 & 60.29 & 58.56 & 60.34 & 62.46 & 55.95 \\
\hline $\mathrm{TiO}_{2}$ & 0.70 & 0.85 & 0.84 & 0.81 & 0.80 & 0.94 \\
\hline $\mathrm{Al}_{2} \mathrm{O}_{3}$ & 17.20 & 17.94 & 19.22 & 18.90 & 17.45 & 19.80 \\
\hline FeOtot & 6.57 & 7.68 & 8.17 & 7.80 & 7.24 & 9.01 \\
\hline $\mathrm{MnO}$ & 0.06 & 0.07 & 0.08 & 0.07 & 0.08 & 0.10 \\
\hline $\mathrm{MgO}$ & 2.61 & 3.27 & 3.40 & 3.37 & 2.97 & 3.74 \\
\hline $\mathrm{CaO}$ & 0.98 & 1.32 & 1.07 & 1.32 & 1.68 & 2.40 \\
\hline $\mathrm{Na}_{2} \mathrm{O}$ & 1.75 & 1.68 & 1.89 & 1.81 & 2.24 & 2.37 \\
\hline $\mathrm{K}_{2} \mathrm{O}$ & 4.29 & 4.73 & 4.40 & 3.97 & 3.73 & 3.36 \\
\hline $\mathrm{P}_{2} \mathrm{O}_{5}$ & 0.24 & 0.24 & 0.26 & 0.17 & 0.15 & 0.15 \\
\hline $\mathrm{S}$ & 0.05 & 0.07 & 0.34 & 0.35 & 0.15 & 0.56 \\
\hline Total & 99.15 & 98.14 & 98.23 & 98.91 & 98.95 & 98.38 \\
\hline $\mathrm{Rb}(\mathrm{ppm})$ & - & - & - & - & 174 & - \\
\hline $\mathrm{Sr}$ & 111 & 124 & 113 & 145 & 180 & 180 \\
\hline $\mathrm{Ba}$ & 630 & 734 & 888 & 920 & 919 & 932 \\
\hline $\mathrm{Zn}$ & 132 & 154 & 148 & 156 & 133 & 178 \\
\hline $\mathrm{Zr}$ & 193 & 204 & 163 & 168 & 210 & 188 \\
\hline $\mathrm{Cr}$ & 263 & 292 & 270 & 251 & 186 & 250 \\
\hline $\mathrm{V}$ & 123 & 176 & 170 & 161 & 136 & 220 \\
\hline Th & - & - & - & - & 16 & - \\
\hline U & - & - & - & - & 3 & - \\
\hline $\mathrm{Cs}$ & - & - & - & - & 7 & - \\
\hline $\mathrm{Y}$ & - & - & - & - & 7 & - \\
\hline $\mathrm{La}$ & - & - & - & - & 43 & - \\
\hline
\end{tabular}

sillimanite has also formed during the relatively late decomposition of cordierite (Fig. 7c), when reaction (4) was reversed.

\section{K-feldspar}

$\mathrm{K}$-feldspar is syn- to late-kinematic in relation to $\mathrm{S}_{2}$. In the sillimanite-K-feldspar zone, this is indicated by the presence of folded $\left(\mathrm{F}_{3}\right)$ mica gneisses with $\mathrm{K}$-feldspar porphyroblasts containing $\mathrm{S}_{2}$ parallel biotite inclusions, or $\mathrm{K}$-feldspar that occurs as interstitial material between other minerals. In the high-grade mica gneisses these K-feldspar porphyroblasts have often been reoriented by the sliding of metamorphically differentiated layers on fold limbs during $\mathrm{F}_{3}$ or $\mathrm{F}_{3 \mathrm{~b}}$ folding (Fig. 7d).

Later K-feldspar crystallized around older Kfeldspars in the garnet-cordierite-sillimanite mica gneisses (Fig. 7c). The later K-feldspar is usually free of inclusions, but in places can contain cordierite and garnet.

\section{Garnet and cordierite}

The $S_{2}$ schistosity curves around a few subhedral garnets in the andalusite mica schists. Most of the cordierite in high-grade rocks is synkinematic to $\mathrm{F}_{2}$ but prekinematic to $\mathrm{F}_{3 \mathrm{~b}}$ folds (Fig. 7d). Garnet and cordierite have also crystallized in the anatectic patches in the high-grade mica gneisses: some of these patches lie in the axial planes of $F_{3 b}$.

\section{CHEMICAL COMPOSITION OF THE METAPELITES AND THEIR MINERALS}

\section{Metapelites}

The metapelites studied have excess aluminium in 
Table 4. Average chemical composition of biotite in metapelites as a function of metamorphic zoning in the Seinäjoki-Ilmajoki area. $n=$ amount of analyses. Oxygen: Bt 11 .

\begin{tabular}{lcccrrr}
\hline & $\begin{array}{c}\text { And } \\
\text { zone } \\
(\mathrm{n}=6)\end{array}$ & $\begin{array}{c}\text { Sil-Ms } \\
\text { zone } \\
(\mathrm{n}=3)\end{array}$ & $\begin{array}{c}\text { Sil-Kfs } \\
\text { zone } \\
(\mathrm{n}=3)\end{array}$ & $\begin{array}{c}\text { Crd-Kfs } \\
\text { zone } \\
(\mathrm{n}=6)\end{array}$ & $\begin{array}{c}\text { Grt-Crd- } \\
\text { Kfs zone } \\
(\mathrm{n}=7)\end{array}$ & $\begin{array}{c}\text { Contact } \\
\text { aureole } \\
(\mathrm{n}=7)\end{array}$ \\
\hline $\mathrm{SiO}_{2}(\mathrm{wt}-\%)$ & 35.40 & 35.20 & 35.33 & 35.42 & 35.70 & 35.89 \\
$\mathrm{TiO}_{2}$ & 1.87 & 2.13 & 2.33 & 2.80 & 3.11 & 4.19 \\
$\mathrm{Al}_{2} \mathrm{O}_{3}$ & 19.80 & 19.93 & 19.80 & 19.03 & 18.73 & 17.96 \\
$\mathrm{FeOtot}$ & 19.32 & 17.67 & 18.63 & 18.47 & 16.86 & 17.18 \\
$\mathrm{MnO}$ & 0.15 & 0.16 & 0.15 & 0.10 & 0.06 & 0.04 \\
$\mathrm{MgO}$ & 8.68 & 9.23 & 9.23 & 9.70 & 10.77 & 10.18 \\
$\mathrm{CaO}$ & 0.04 & 0.03 & 0.02 & 0.03 & 0.01 & 0.02 \\
$\mathrm{Na}{ }_{2} \mathrm{O}$ & 0.20 & 0.25 & 0.29 & 0.17 & 0.18 & 0.14 \\
$\mathrm{~K}_{2} \mathrm{O}$ & 8.40 & 8.80 & 8.97 & 8.33 & 9.29 & 9.30 \\
$\mathrm{Total}$ & 93.86 & 93.40 & 94.75 & 94.05 & 94.71 & 94.90 \\
$\mathrm{Si}$ & 2.977 & 2.963 & 2.943 & 2.950 & 2.940 & 2.945 \\
$\mathrm{Al}$ & 1.252 & 1.262 & 1.240 & 1.192 & 1.160 & 1.108 \\
$\mathrm{Ti}$ & 0.118 & 0.135 & 0.146 & 0.175 & 0.193 & 0.259 \\
$\mathrm{Mg}$ & 1.089 & 1.159 & 1.147 & 1.204 & 1.323 & 1.245 \\
$\mathrm{Fe}$ & 1.359 & 1.244 & 1.298 & 1.286 & 1.161 & 1.179 \\
$\mathrm{Mn}$ & 0.010 & 0.110 & 0.010 & 0.007 & 0.004 & 0.003 \\
$\mathrm{Ca}$ & 0.004 & 0.003 & 0.002 & 0.003 & 0.001 & 0.002 \\
$\mathrm{Na}$ & 0.032 & 0.040 & 0.047 & 0.027 & 0.029 & 0.023 \\
$\mathrm{~K}$ & 0.902 & 0.945 & 0.953 & 0.885 & 0.976 & 0.973 \\
\hline
\end{tabular}

relation to alkalies and calcium (Table 3, see also Appendix 1). The chemical compositions of rocks in the different metamorphic zones are relatively similar, except for those of the contact aureole of the Luopa quartz monzonite stock (Table 3). Thus, the principle of metamorphic facies established by Eskola (1915) is applicable.

The similar chemical composition of metapelites in the regional metamorphic zones studied agrees with the relatively low amount of anatectic neosome: the content of $\mathrm{K}_{2} \mathrm{O}$ has not notably decreased as a result of the formation of granitic neosome (Table 3). Moreover, the fairly high concentrations of $\mathrm{Rb}$ and $\mathrm{Cs}$ in the high-grade mica gneisses indicate that element depletion during metamorphism was not intensive (cf. Rudnick \& Presper 1990). The concentrations of $\mathrm{Sr}$ and $\mathrm{Ba}$ in the highest-grade rocks appear to be higher than in the mica schists.

\section{Biotite}

The analysed points are in cores of biotites, which are not in contact with other Fe-Mg silicates. The mode of biotite is high in each metamorphic zone (Table 2).

The amount of titanium and the ratio of $\mathrm{Mg}$ $\mathrm{Fe}$ increase, while the amount of aluminium and manganese decreases in biotites as a function of increasing metamorphic grade (Table 4, Fig. 8). In the andalusite, sillimanite-muscovite, sillimanite-K-feldspar and cordierite-K-feldspar zones the aforementioned overall increase of titanium is also compensated by a decrease in $\mathrm{Ti}$ with increasing $\mathrm{Mg} /(\mathrm{Mg}+\mathrm{Fe}$ ) (Fig. 8). Many high-grade metamorphic terrains yield similar compositional trends (e.g. Guidotti et al. 1977, Bailey 1984, Schreurs 1985).

The biotite in the andalusite zone, in the sillimanite-muscovite zone, and in the sillimanite-Kfeldspar zone has greenish pleochroism $(\beta=\gamma)$. In the cordierite-K-feldspar zone, the pleochroic colour has a brownish shade, and in the garnet- 


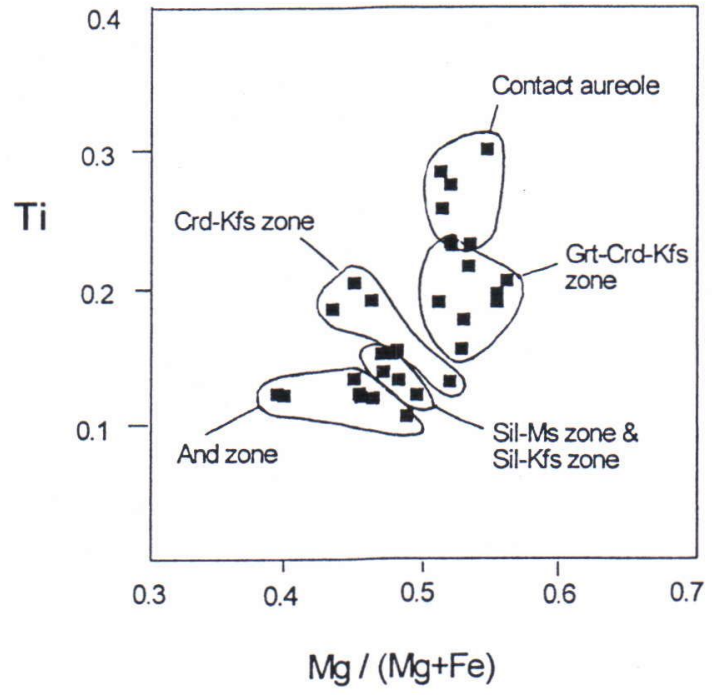

Fig. 8. Plot of Ti vs. $\mathrm{Mg} /(\mathrm{Mg}+\mathrm{Fe})$ of biotites from various metamorphic zones of the Seinäjoki-Ilmajoki area. Oxygen: Bt 11.
cordierite-K-feldspar zone it is greenish brown with a reddish shade. In the contact aureole of the Luopa quartz monzonite, the pleochroic colour of biotite is brownish red.

\section{Garnet and cordierite}

The present microprobe analyses of garnet and cordierite represent different parts of minerals and texturally different coexisting pairs (see Table 5). The rims of garnets usually contain slightly more $\mathrm{Mn}$ than their cores. The amount of $\mathrm{MgO}$ in the garnet is maximum of $5.4 \mathrm{wt} \%$ and in the cordierite $9.5 \mathrm{wt} \%$.

The sum of oxides in the cordierites is often relatively low (96-98 wt\%) probably due the $\mathrm{H}_{2} \mathrm{O}$ content of the mineral (see Table 5). The $\mathrm{H}_{2} \mathrm{O}$ content (wet chemical analysis) of cordierite from garnet-cordierite-sillimanite mica gneiss taken

Table 5. Microprobe analyses and geothermometric estimations of garnet-cordierite pairs from the garnet-cordierite-K-feldspar zone. Temperatures are calculated using the following thermometers: $T_{1}$ (Holdaway \& Lee 1977) and $T_{2}$ (Perchuk 1989). Assumed pressure is $5 \mathrm{kbar}$ for $T_{1}$ and $T_{2}$. Equilibrium = cores of equilibrated mineral pair. Disequilibrium $=$ rims of coexisting minerals. Corona $=$ analysed points from coronatic pairs. Oxygens: Grt 12, Crd 18.

\begin{tabular}{|c|c|c|c|c|c|c|c|c|c|c|}
\hline \multirow{2}{*}{$\begin{array}{l}\text { Structure } \\
\text { Sample } \\
\text { Minerals }\end{array}$} & \multicolumn{2}{|c|}{$\begin{array}{l}\text { Equilibrium } \\
800-B / 1-2\end{array}$} & \multicolumn{2}{|c|}{$\begin{array}{c}\text { Equilibrium } \\
800-B / 3-4\end{array}$} & \multicolumn{2}{|c|}{$\begin{array}{l}\text { Equilibrium } \\
\text { 800-BVA/25-26 }\end{array}$} & \multicolumn{2}{|c|}{$\begin{array}{l}\text { Equilibrium } \\
512 / 19-20\end{array}$} & \multicolumn{2}{|c|}{$\begin{array}{c}\text { Disequilibrium } \\
150-\mathrm{B} / 8-9\end{array}$} \\
\hline & Grt & Crd & Grt & Crd & Grt & Crd & Grt & Crd & Grt & $\mathrm{Crd}$ \\
\hline $\mathrm{SiO}_{2}$ & 37.25 & 48.37 & 37.28 & 48.21 & 38.03 & 48.46 & 37.53 & 47.26 & 36.88 & 48.07 \\
\hline $\mathrm{TiO}_{2}$ & 0.01 & 0.00 & 0.02 & 0.01 & 0.02 & 0.00 & 0.02 & 0.00 & 0.00 & 0.01 \\
\hline $\mathrm{Al}_{2} \mathrm{O}_{3}$ & 21.26 & 32.85 & 21.05 & 32.64 & 21.53 & 32.19 & 21.50 & 31.88 & 20.94 & 32.59 \\
\hline FeOtot & 33.44 & 8.16 & 33.98 & 7.13 & 32.00 & 7.20 & 33.48 & 7.27 & 33.74 & 7.62 \\
\hline $\mathrm{MnO}$ & 1.19 & 0.04 & 1.11 & 0.05 & 1.02 & 0.07 & 1.20 & 0.11 & 1.45 & 0.06 \\
\hline $\mathrm{MgO}$ & 5.11 & 8.80 & 5.27 & 9.23 & 5.26 & 8.27 & 5.01 & 8.66 & 4.95 & 8.92 \\
\hline $\mathrm{CaO}$ & 1.09 & 0.00 & 1.04 & 0.05 & 0.97 & 0.01 & 0.88 & 0.01 & 0.96 & 0.05 \\
\hline $\mathrm{Na}_{2} \mathrm{O}$ & 0.04 & 0.03 & 0.00 & 0.21 & 0.12 & 0.17 & 0.05 & 0.15 & 0.25 & 0.21 \\
\hline $\mathrm{K}_{2} \mathrm{O}$ & 0.16 & 0.20 & 0.12 & 0.01 & 0.09 & 0.03 & 0.01 & 0.04 & 0.08 & 0.01 \\
\hline Total & 99.55 & 98.45 & 99.87 & 97.54 & 99.04 & 96.40 & 99.68 & 95.38 & 99.25 & 97.54 \\
\hline $\mathrm{T}_{1}\left({ }^{\circ} \mathrm{C}\right)$ & \multicolumn{2}{|c|}{686} & \multicolumn{2}{|c|}{640} & \multicolumn{2}{|c|}{689} & \multicolumn{2}{|c|}{652} & \multicolumn{2}{|c|}{651} \\
\hline $\mathrm{T}_{2}\left({ }^{\circ} \mathrm{C}\right)$ & \multicolumn{2}{|c|}{722} & \multicolumn{2}{|c|}{673} & \multicolumn{2}{|c|}{729} & \multicolumn{2}{|c|}{689} & \multicolumn{2}{|c|}{683} \\
\hline $\mathrm{Si}$ & 3.277 & 5.656 & 3.272 & 5.661 & 3.329 & 5.744 & 3.291 & 5.680 & 3.265 & 5.659 \\
\hline $\mathrm{Al}$ & 1.407 & 2.889 & 1.389 & 2.882 & 1.417 & 2.870 & 1.418 & 2.882 & 1.394 & 2.885 \\
\hline $\mathrm{Ti}$ & 0.001 & 0.000 & 0.001 & 0.001 & 0.001 & 0.000 & 0.001 & 0.000 & 0.000 & 0.001 \\
\hline $\mathrm{Mg}$ & 0.670 & 1.534 & 0.689 & 1.616 & 0.686 & 1.461 & 0.655 & 1.552 & 0.653 & 1.565 \\
\hline $\mathrm{Fe}$ & 2.460 & 0.798 & 2.494 & 0.700 & 2.343 & 0.714 & 2.455 & 0.731 & 2.498 & 0.750 \\
\hline Mn & 0.089 & 0.004 & 0.083 & 0.005 & 0.076 & 0.007 & 0.089 & 0.011 & 0.109 & 0.006 \\
\hline $\mathrm{Ca}$ & 0.103 & 0.000 & 0.098 & 0.006 & 0.091 & 0.001 & 0.083 & 0.001 & 0.091 & 0.006 \\
\hline $\mathrm{Na}$ & 0.007 & 0.007 & 0.000 & 0.048 & 0.020 & 0.039 & 0.009 & 0.035 & 0.043 & 0.048 \\
\hline K & 0.018 & 0.030 & 0.013 & 0.001 & 0.010 & 0.005 & 0.001 & 0.006 & 0.009 & 0.002 \\
\hline
\end{tabular}


Table 5. (continues)

\begin{tabular}{|c|c|c|c|c|c|c|c|c|c|c|}
\hline \multirow{2}{*}{$\begin{array}{l}\text { Structure } \\
\text { Sample } \\
\text { Minerals }\end{array}$} & \multicolumn{2}{|c|}{$\begin{array}{c}\text { Disequilibrium } \\
150-\mathrm{B} / 11-12\end{array}$} & \multicolumn{2}{|c|}{$\begin{array}{c}\text { Disequilibrium } \\
150-\mathrm{B} / 11-10\end{array}$} & \multicolumn{2}{|c|}{$\begin{array}{c}\text { Disequilibrium } \\
512 / 15-16\end{array}$} & \multicolumn{2}{|c|}{$\begin{array}{c}\text { Corona } \\
340-\mathrm{D} / 13-14\end{array}$} & \multicolumn{2}{|c|}{$\begin{array}{c}\text { Corona } \\
145 / 1\end{array}$} \\
\hline & Grt & Crd & Grt & $\mathrm{Crd}$ & Grt & Crd & Grt & Crd & Grt & $\mathrm{Crd}$ \\
\hline $\mathrm{SiO}_{2}$ & 37.00 & 48.21 & 37.39 & 48.12 & 37.21 & 47.85 & 37.86 & 48.84 & 37.80 & 48.90 \\
\hline $\mathrm{TiO}_{2}$ & 0.00 & 0.05 & 0.00 & 0.02 & 0.04 & 0.01 & 0.03 & 0.06 & 0.01 & 0.03 \\
\hline $\mathrm{Al}_{2} \mathrm{O}_{3}$ & 21.53 & 33.24 & 21.45 & 32.96 & 21.21 & 32.35 & 21.88 & 33.75 & 22.20 & 33.80 \\
\hline FeOtot & 34.06 & 7.25 & 34.08 & 7.91 & 33.86 & 7.39 & 33.78 & 7.25 & 34.10 & 7.40 \\
\hline $\mathrm{MnO}$ & 1.51 & 0.07 & 1.37 & 0.12 & 1.14 & 0.05 & 1.21 & 0.07 & 1.30 & 0.10 \\
\hline $\mathrm{MgO}$ & 4.85 & 9.32 & 4.92 & 8.85 & 5.10 & 9.09 & 5.11 & 9.38 & 4.90 & 9.40 \\
\hline $\mathrm{CaO}$ & 0.98 & 0.02 & 0.94 & 0.00 & 1.01 & 0.03 & 0.95 & 0.03 & 1.00 & 0.10 \\
\hline $\mathrm{Na}_{2} \mathrm{O}$ & 0.13 & 0.21 & 0.13 & 0.20 & 0.12 & 0.18 & 0.16 & 0.44 & 0.00 & 0.05 \\
\hline $\mathrm{K}_{2} \mathrm{O}$ & 0.00 & 0.03 & 0.01 & 0.03 & 0.00 & 0.02 & 0.02 & 0.07 & 0.00 & 0.00 \\
\hline Total & 100.06 & 98.40 & 100.29 & 98.21 & 99.69 & 96.97 & 101.00 & 99.89 & 101.31 & 99.78 \\
\hline $\mathrm{T}_{1}\left({ }^{\circ} \mathrm{C}\right)$ & \multicolumn{2}{|c|}{619} & \multicolumn{2}{|c|}{659} & \multicolumn{2}{|c|}{645} & \multicolumn{2}{|c|}{633} & \multicolumn{2}{|c|}{625} \\
\hline $\mathrm{T}_{2}\left({ }^{\circ} \mathrm{C}\right)$ & \multicolumn{2}{|c|}{649} & \multicolumn{2}{|c|}{695} & \multicolumn{2}{|c|}{679} & \multicolumn{2}{|c|}{666} & \multicolumn{2}{|c|}{657} \\
\hline $\mathrm{Si}$ & 3.254 & 5.626 & 3.272 & 5.640 & 3.271 & 5.659 & 3.280 & 5.619 & 3.271 & 5.627 \\
\hline $\mathrm{Al}$ & 1.424 & 2.917 & 1.412 & 2.905 & 1.402 & 2.877 & 1.425 & 2.920 & 1.445 & 2.925 \\
\hline $\mathrm{Ti}$ & 0.000 & 0.004 & 0.000 & 0.002 & 0.003 & 0.001 & 0.002 & 0.005 & 0.001 & 0.003 \\
\hline $\mathrm{Mg}$ & 0.636 & 1.621 & 0.642 & 1.546 & 0.668 & 1.603 & 0.660 & 1.609 & 0.632 & 1.613 \\
\hline $\mathrm{Fe}$ & 2.505 & 0.708 & 2.494 & 0.775 & 2.490 & 0.731 & 2.447 & 0.698 & 2.468 & 0.712 \\
\hline $\mathrm{Mn}$ & 0.112 & 0.007 & 0.102 & 0.012 & 0.085 & 0.005 & 0.089 & 0.007 & 0.095 & 0.010 \\
\hline $\mathrm{Ca}$ & 0.092 & 0.003 & 0.088 & 0.000 & 0.095 & 0.004 & 0.088 & 0.004 & 0.093 & 0.012 \\
\hline $\mathrm{Na}$ & 0.022 & 0.048 & 0.022 & 0.045 & 0.020 & 0.041 & 0.027 & 0.098 & 0.000 & 0.011 \\
\hline $\mathrm{K}$ & 0.000 & 0.004 & 0.001 & 0.004 & 0.000 & 0.003 & 0.002 & 0.010 & 0.000 & 0.000 \\
\hline
\end{tabular}

Table 5. (continues)

\begin{tabular}{|c|c|c|c|c|c|c|c|c|}
\hline \multirow{2}{*}{$\begin{array}{l}\text { Structure } \\
\text { Sample } \\
\text { Minerals }\end{array}$} & \multicolumn{2}{|c|}{$\begin{array}{l}\text { Corona } \\
145 / \text { PII5-7 }\end{array}$} & \multicolumn{2}{|c|}{$\begin{array}{c}\text { Corona } \\
\text { 316-HMMOK }\end{array}$} & \multicolumn{2}{|c|}{$\begin{array}{l}\text { Corona } \\
\text { 145/R1-OK }\end{array}$} & \multicolumn{2}{|c|}{$\begin{array}{c}\text { Core of coarse grains } \\
\text { 390-S28 791A16 }\end{array}$} \\
\hline & Grt & Crd & Grt & $\mathrm{Crd}$ & Grt & Crd & Grt & Grt \\
\hline $\mathrm{SiO}_{2}$ & 37.56 & 49.00 & 37.18 & 47.95 & 38.16 & 48.92 & 39.19 & 37.35 \\
\hline $\mathrm{TiO}_{2}$ & 0.05 & 0.03 & 0.01 & 0.01 & 0.02 & 0.01 & 0.03 & 0.03 \\
\hline $\mathrm{Al}_{2} \mathrm{O}_{3}$ & 21.86 & 33.97 & 21.38 & 32.39 & 21.71 & 32.45 & 21.88 & 21.46 \\
\hline FeOtot & 33.95 & 6.89 & 34.38 & 7.02 & 34.16 & 6.82 & 31.02 & 32.06 \\
\hline $\mathrm{MnO}$ & 1.26 & 0.10 & 1.22 & 0.04 & 1.14 & 0.05 & 1.24 & 2.10 \\
\hline $\mathrm{MgO}$ & 4.91 & 9.51 & 4.83 & 8.91 & 4.88 & 8.98 & 5.36 & 5.11 \\
\hline $\mathrm{CaO}$ & 1.07 & 0.05 & 1.07 & 0.01 & 0.94 & 0.02 & 0.94 & 1.12 \\
\hline $\mathrm{Na}_{2} \mathrm{O}$ & 0.16 & 0.23 & 0.02 & 0.12 & 0.02 & 0.10 & 0.07 & 0.03 \\
\hline $\mathrm{K}_{2} \mathrm{O}$ & 0.00 & 0.07 & 0.00 & 0.00 & 0.00 & 0.02 & 0.03 & 0.01 \\
\hline Total & 100.82 & 99.85 & 100.09 & 96.45 & 101.03 & 97.37 & 99.76 & 99.27 \\
\hline $\mathrm{T}_{1}\left({ }^{\circ} \mathrm{C}\right)$ & \multicolumn{2}{|c|}{606} & \multicolumn{2}{|c|}{619} & \multicolumn{2}{|c|}{614} & & \\
\hline $\mathrm{T}_{2}\left({ }^{\circ} \mathrm{C}\right)$ & \multicolumn{2}{|c|}{637} & \multicolumn{2}{|c|}{650} & \multicolumn{2}{|c|}{645} & & \\
\hline $\mathrm{Si}$ & 3.268 & 5.628 & 3.265 & 5.687 & 3.302 & 5.728 & 3.378 & 3.286 \\
\hline Al & 1.430 & 2.934 & 1.412 & 2.889 & 1.413 & 2.857 & 1.418 & 1.420 \\
\hline $\mathrm{Ti}$ & 0.003 & 0.003 & 0.001 & 0.001 & 0.001 & 0.001 & 0.002 & 0.002 \\
\hline $\mathrm{Mg}$ & 0.637 & 1.628 & 0.632 & 1.575 & 0.629 & 1.568 & 0.689 & 0.670 \\
\hline $\mathrm{Fe}$ & 2.470 & 0.662 & 2.525 & 0.696 & 2.472 & 0.668 & 2.236 & 2.359 \\
\hline $\mathrm{Mn}$ & 0.093 & 0.010 & 0.091 & 0.004 & 0.084 & 0.005 & 0.091 & 0.156 \\
\hline $\mathrm{Ca}$ & 0.100 & 0.006 & 0.101 & 0.001 & 0.087 & 0.003 & 0.087 & 0.106 \\
\hline $\mathrm{Na}$ & 0.027 & 0.051 & 0.003 & 0.028 & 0.003 & 0.023 & 0.012 & 0.005 \\
\hline K & 0.000 & 0.010 & 0.000 & 0.000 & 0.000 & 0.003 & 0.003 & 0.001 \\
\hline
\end{tabular}


from the southern part of the study area is 1.43 wt\% (Pehrman 1932).

\section{GEOTHERMOMETRY}

The garnets and cordierites used in the present P-T determinations were taken from the garnetcordierite-K-feldspar zone, maintaining a horizontal distance of more than one kilometre from the Luopa quartz monzonite stock. The contact metamorphic effects of the Luopa quartz monzonite are therefore probably minimal. However, the contact of the stock has a relatively gentle dip to the northwest and, thus, the real distance between the samples and the quartz monzonite may be less than one kilometre.

Metamorphic temperatures were calculated using the garnet-cordierite thermometers of Holdaway and Lee (1977) and of Perchuk (1989) (Table 5). Garnet-cordierite pairs are not ideal for making geobarometric estimates because of the unknown $\mathrm{H}_{2} \mathrm{O}$ content of the cordierite. No geobarometric estimates are made in the present study, but a pressure assumption of 5 kbar was used in geothermometric estimates. Retrogressive kyanite in the garnet-cordierite-sillimanite mica gneisses indicates a relatively high (c. 5 kbar) pressure during the metamorphic peak.

The analysed mineral points are from (1) the cores of equilibrated pairs, (2) the rims of coexisting, but probably disequilibrated pairs, and (3) those pairs having corona structures (Table 5). Temperature estimates from equilibrated minerals range from $640{ }^{\circ} \mathrm{C}$ to $729^{\circ} \mathrm{C}$, but the estimates from rims and corona pairs are slightly lower, from $614{ }^{\circ} \mathrm{C}$ to $695{ }^{\circ} \mathrm{C}$ (Table 5). The highest temperatures were obtained with the thermometer of Perchuk (1989). The temperature estimates $\left(<750{ }^{\circ} \mathrm{C}\right)$ obtained agree with the fact that zircons in metapelites in the southern Ilmajoki area were not reset during the Svecofennian regional metamorphic peak. A U-Pb zircon age (c. $2.4 \mathrm{Ga}$ ) reported from these metapelites reflects the mixture of Archaean and Palaeoproterozoic material (see Huhma et al. 1991, Mäkitie \& Lahti 1991).

\section{SUMMARY AND DISCUSSION}

Regional metamorphism in the Seinäjoki-Ilmajoki area has the following characteristic features. The highest grade of metamorphism took place at lower granulite facies conditions with a facies-series of the low-pressure intermediate type, and with metamorphic temperatures of about $730{ }^{\circ} \mathrm{C}$. Retrogressive muscovite is practically absent and granitic neosomes occur in relatively low amounts, usually as patches and not as networks of narrow veins. Equilibrated garnet-cordierite pairs are rare and in places garnet surrounds cordierite. Retrogressive, minor kyanite occurs in the garnetcordierite-sillimanite mica gneisses while retrogressive andalusite is absent. The 'muscovite out' -isograd is an irregular line. Regional metamorphism was obviously contemporary with the emplacement of $1882 \pm 9$ Ma old synkinematic tonalites. The lowest grade metapelites occur close to pegmatite granites and to the hinge of a regionalscale antiform, and the highest grade rocks are near the Luopa mangeritic stock (see Figs. 1 and 2).

The dominant schistosity $\left(\mathrm{S}_{2}\right)$ in the mica schists is a biotite and muscovite metamorphic axial plane foliation formed during isoclinal $\mathrm{F}_{2}$ folding. The $S_{1}$ schistosity, usually parallel to $S_{2}$, is very weak. In areas of high-grade mica gneisses, tight to isoclinal late-metamorphic $\mathrm{F}_{3}$ and $\mathrm{F}_{3 \mathrm{~b}}$ folds, with the dominant $S_{3}$ and $S_{3 b}$ foliations associated, deform $\mathrm{S}_{2}$. Consequently a composite schistosity $\left(S_{0} \pm S_{1} \pm S_{2} \pm S_{3}\right.$ or $\left.S_{3 b}\right)$ is very common. $\mathrm{F}_{3 \mathrm{~b}}$ fold axes have steeper plunges than $\mathrm{F}_{3}$ fold axes (Fig. 2a), but the reason for this difference is not clear. The vergence of $F_{3}$ and $F_{3 b}$ folds indicates regional-scale parasitic fold structures. Younger small-scale crenulating deformations $\left(\mathrm{F}_{4}\right.$ and $\mathrm{F}_{5}$ ) are best seen in the ductile mica schist.

The regional metamorphic isograds are often subparallel to the dominant $\mathrm{E}-\mathrm{W}$-trending axes of $F_{3}$ and $F_{3 b}$ folds (see Figs. 1 and 2). The comparatively well-preserved layering in mica gneisses is due to, for example, relatively low strain during the main fold phases $\left(\mathrm{F}_{2}, \mathrm{~F}_{3}\right.$ and $\left.\mathrm{F}_{3 \mathrm{~b}}\right)$, the absence of mineral growth during $F_{3}$ and $F_{3 b}$ folding events, the relatively minor formation of 


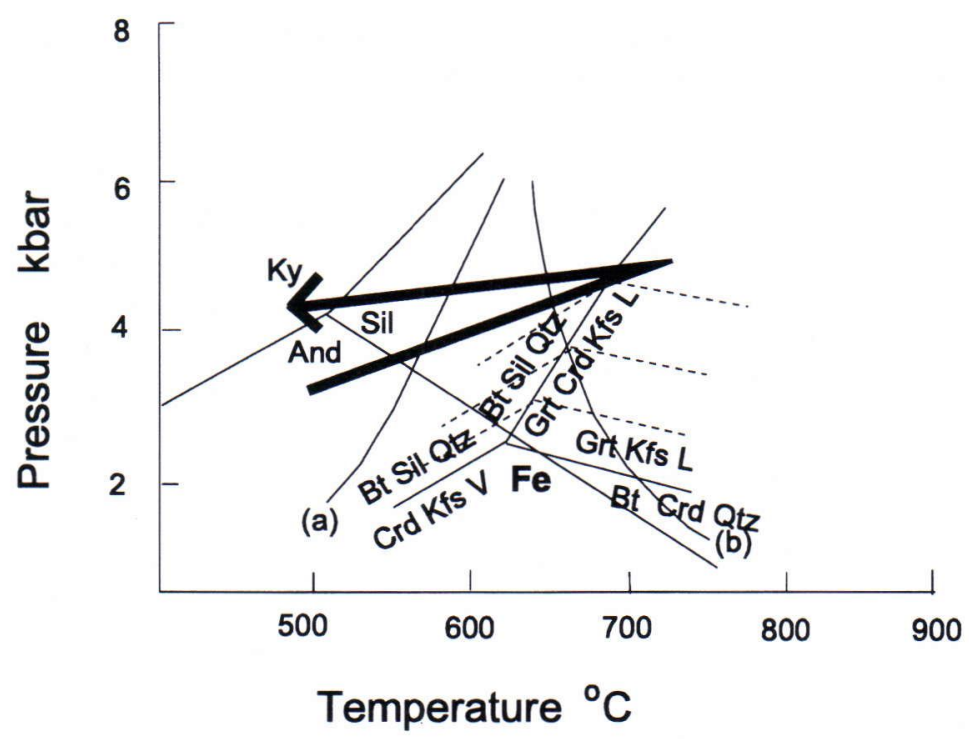

Fig. 9. Petrogenetic grid for metapelites and probable P-T path (thick arrow) for the regional metamorphism of the Seinäjoki-Ilmajoki area. The dehydration reaction (at $P_{H 20}=0.4 P_{\text {tot }}$ ) of biotite-sillimanite-quartz assemblage is adjusted according to Holdaway and Lee (1977) and the dashed lines represent contours for molar $\mathrm{Fe} /$ $(\mathrm{Fe}+\mathrm{Mg})$ of cordierite. The triple point of aluminium silicates is after Salje (1986). Muscovite breakdown reaction (a) is from Chatterjee and Johannes (1974) and the granite minimum melting curve (b) is from Kerrick (1972).

melts or late neosomes, and the absence of muscovitization.

From observations of the relationship between metamorphism and deformation in the SeinäjokiIlmajoki area, it has been concluded that the age of metamorphism is approximately same in areas of higher and lower grade. During late-metamorphic $\mathrm{F}_{3 \mathrm{~b}}$ folding, the metamorphic temperature in the southern part of the study area remained quite high because some granitic lenses, containing garnet and cordierite, formed along axial surfaces. From the isotopic $\mathrm{U}-\mathrm{Pb}$ age of monazite in the garnet-cordierite-sillimanite mica gneisses, it has been estimated that crustal cooling below 600-650 ${ }^{\circ} \mathrm{C}$ took place c. $1.86 \mathrm{Ga}$ ago (Mäkitie \& Lahti 1991). The crust was locally heated during the emplacement of the $1871 \pm 1$ Ma old, post-kinematic Luopa quartz monzonite stock. This deformed the $\mathrm{F}_{3 \mathrm{~b}}$ folds and intersected the main foliation of tonalites forming a narrow overprinting granulitegrade contact aureole. The occurrence in the mica gneisses of the garnet-cordierite-K-feldspar zone of a folded biotite-rich schistosity $\left(S_{2}\right)$ and of anatectic veins in $\mathrm{F}_{3}$ axial surfaces is also evidence for polymetamorphism. The southern Ilmajoki area did not undergo notable deformation after $\mathrm{c}$. $1.87 \mathrm{Ga}$.

A probable P-T path for the regional metamorphism of the Seinäjoki-Ilmajoki area is given in Fig. 9. The occurrence of retrogressive kyanite and the absence of retrogressive andalusite and muscovitization in the regional metamorphic garnetcordierite-sillimanite mica gneisses may indicate nearly isobaric cooling of the crust. Moreover, the post-kinematic Luopa quartz monzonite may indicate heating processes in the lower crust with the formation of relatively dense magmas. This body possibly slowed the isostatic uplift of the crust locally, and this in turn partly caused the absence of retrogressive andalusite and of muscovitization. The anatectic melts formed in the garnet-cordierite-K-feldspar zone were intruded upwards in the crust into areas of lower metamorphic grade, where they intruded as pegmatite granites and pegmatites. In the high-grade mica gneisses, the removal of this melt extracted dissolved $\mathrm{H}_{2} \mathrm{O}$ 
and slowed down the progress of retrograde hydration reactions, such as those that occur in muscovitization. The P-T path shown only applies to the area studied because, about $20 \mathrm{~km}$ southeast, near the village of Ala-Valli, and about $30 \mathrm{~km}$ north, near the parish of Ylistaro, there are migmatitic garnet-cordierite mica gneisses that contain retrogressive andalusite and have undergone muscovitization. These last-mentioned areas do not contain any products of mangeritic magmatism and major shear zones partly separate them from the study area.

Unlike in southern Finland (see Kilpeläinen 1998 and references therein), the Seinäjoki area appears not to contain a growth of metamorphic micas $\left(\mathrm{S}_{3}\right)$ in the mica schists of the andalusite zone, when the mica gneisses of the cordierite-Kfeldspar and garnet-cordierite-K-feldspar zones have undergone late-metamorphic $\mathrm{F}_{3}$ folding. In the Seinäjoki-Ilmajoki area, the muscovite-sillimanite zone is clearly wider than in the high-temperature/low-pressure Rantasalmi area of southeastern Finland (see Korsman 1977, Korsman \& Kilpeläinen 1986). In large-scale regional correlation, it should be noted that the lowest metamorphic grade in the Seinäjoki area is above greenschist-facies. Thus, it is not necessary that an earlier schistosity $\left(\mathrm{S}_{1}\right)$ observed elsewhere in Finland has been preserved or even developed in the Seinäjoki area. The feature called $S_{1}$ in this study is very weak and subject to interpretation.

The Luopa quartz monzonite is some $15 \mathrm{Ma}$ younger than the pyroxene granitoids in the Pielavesi area, Raahe-Ladoga zone, eastern Finland (cf. Hölttä 1988). The Luopa intrusion was emplaced after the regional metamorphic culmination while the pyroxene granitoids of the Pielavesi area intruded mostly during it (see Hölttä 1995).

In the study area, regional metamorphism culminated at the same time $(\sim 1885 \mathrm{Ma}$ ago $)$ as the intense first phase of metamorphism in southern Finland (see Korsman et al. 1984). The high-grade terrain studied did not undergo the strong later thermal pulse (1.86-1.81 Ga ago) with intense potassium granite migmatization that is characteristic of the southern part of southern Finland (see Korsman ibid.). The Seinäjoki-Ilmajoki area also differs from the northern part of southern Finland (which has been called the area of tonalite migmatites by Korja et al. 1994) because of the abundant aluminium-rich metapelite component and mangeritic magmatism of the former.

ACKNOWLEDGEMENTS. The author thanks the Finnish Academy and the Finnish Cultural Foundation for their grants. I thank Dr. Stefan Bergman, Prof. Ilmari Haapala, Dr. Pentti Hölttä, Dr. Yrjö Kähkönen, Dr. Niilo Kärkkäinen, Dr. Timo Kilpeläinen, Dr. Tapio Koistinen, Prof. Kalevi Korsman, Dr. Seppo I. Lahti, Dr. Hassina Mouri and Dr. Mikko Nironen for their constructive criticism. The revision of the present research was made with the help of the Geological Survey of Finland (GTK). Thanks also go to Mr. Bo Johansson, Mr. Lassi Pakkanen and Mr. Seppo Sivonen for the microprobe determinations, to the Chemistry Laboratories of Rautaruukki Company and of the GTK for the chemical analyses, to Mrs. Tarja Tuimala for the drawing of maps, and to $\mathrm{Mr}$. Graeme Waller for checking the English of the manuscript.

\section{REFERENCES}

Alviola, R. 1989. The granitic pegmatites of the Seinäjoki and Haapaluoma groups. In: Lahti, S.I. (ed.) Symposium of Precambrian granitoids. Petrogenesis, geochemistry and metallogeny, August 14-17, 1989, Helsinki, Finland. Geological Survey of Finland, Guide 26, 41-48.

Bailey, S.W. (ed.) 1984. Micas. Reviews in Mineralogy, Vol. 13. Mineralogical Society of America. 584 p.

Borodaev, Yu.S., Bortnikov, N.S., Mozgova, N.N., Ozerova, N.A., Oivanen, P. \& Yletyinen, V. 1983. Association of the ore minerals in deposits of the Seinäjoki district and the discussion on the ore formation. Bulletin of the Geological Society of Finland 55, 3-23.

Brown, M. 1993. P-T-t evolution of orogenic belts and causes of regional metamorphism. Journal of the Geological Society, London 150, 227-241.

Chatterjee, N.D. \& Johannes, W. 1974. Thermal stability and standard thermodynamic properties of synthetic 2N1-muscovite $\mathrm{KAl}_{2}\left(\mathrm{AlSi}_{3} \mathrm{O}_{10}\right)(\mathrm{OH})_{2}$. Contributions to Mineralogy and Petrology 48, 89-114.

Ehlers, C., Lindroos, A. \& Selonen, O. 1993. The late Svecofennian granite-migmatite zone of southern Finland - a belt of transpressive deformation and granite emplacement. Precambrian Research 64, 259-309.

Eskola, P. 1915. Om sambandet mellan kemisk och min- 
eralogisk sammansätting hos Orijärvi traktens metamorfa bergarter. Bulletin de la Commission Géologique de Finlande 44. 145 p. (in Swedish)

Evans, B. \& Guidotti, C. 1966. The Sillimanite-Potash Feldspar isograd in Western Maine, U.S.A. Contributions to Mineralogy and Petrology 12, 25-62.

Guidotti, C.V., Cheney, J.T. \& Guggenheim, S. 1977. Distribution of titanium between coexisting muscovite and biotite in pelitic schists from northwestern Maine. American Mineralogist 62, 438-448.

Holdaway, M. \& Lee, S. 1977. Fe-Mg cordierite stability in high grade pelitic rocks based on experimental, theoretical and natural observations. Contributions to Mineralogy and Petrology 63, 175-198.

Hölttä, P. 1988. Metamorphic zones and the evolution of the granulite grade metamorphism in the Early Proterozoic Pielavesi area, Central Finland. Geological Survey of Finland, Bulletin 344. 50 p.

Hölttä, P. 1995. Contact metamorphism of the Vaaraslahti pyroxene granitoid intrusion in Pielavesi, Central Finland. In: Hölttä, P. (ed.) Relationship of granitoids, structures and metamorphism at the eastern margin of the Central Finland Granitoid Complex. Geological Survey of Finland, Bulletin 382, 5-26.

Hopgood, A. \& Bowes, D. 1972. Application of structural sequences to the correlation of Precambrian gneisses, Outer Hebrides, Scotland. Geological Society of America, Bulletin 83, 107-128.

Huhma, H., Claesson, S., Kinny, P.D. \& Williams, I.S. 1991. The growth of Early Proterozoic crust: new evidence from Svecofennian detrital zircons. Terra Nova 3, 175-179.

Kerrick, D.M. 1972. Experimental determination of muscovite + quartz stability with $\mathrm{P}_{\mathrm{H} 20}<\mathrm{P}_{\text {tot }}$. American Journal of Science 272, 946-958.

Kilpeläinen, T. 1988. Evolution of deformation and metamorphism as a function of time in the Rantasalmi-Sulkava area, southeastern Finland. In: Korsman, K. (ed.) Tectono-metamorphic evolution of the Raahe-Ladoga zone. Geological Survey of Finland, Bulletin 343, 77-88.

Kilpeläinen, T. 1998. Evolution and 3D modelling of structural and metamorphic patterns of the Palaeoproterozoic crust in the Tampere-Vammala area, southern Finland. Geological Survey of Finland, Bulletin 397. 124 p.

Kiviniemi, A. 1980. Gravity measurements in 1961-1978 and the results of the gravity survey of Finland in 19451978. Publications of the Finnish Geodetic Institute 91. $22 \mathrm{p}$.

Koistinen, T. 1981. Structural evolution of an early Proterozoic stratabound $\mathrm{Cu}-\mathrm{Co}-\mathrm{Zn}$ deposit, Outokumpu, Finland. Transactions of the Royal Society of Edinburgh: Earth Sciences 72, 115-158.

Koistinen, T., Klein, V., Koppelmaa, H., Korsman, K., Lahtinen, R., Nironen, M., Puura, V., Saltykova T., Tikhomirov, S. \& Yanovskiy, A. 1996. Paleoproterozoic Svecofennian orogenic belt in the surroundings of the Gulf of Finland. In: Koistinen, T. (ed.) Explanation to the map of Precambrian basement of the Gulf of Fin- land and surrounding area 1:1 million. Geological Survey of Finland, Special Paper 21, 21-57.

Korja, T., Luosto, U., Korsman, K. \& Pajunen, M. 1994. Geophysical and metamorphic features of the Palaeoproterozoic Svecofennian orogeny and Palaeoproterozoic overprinting on Archaean crust. In: Pajunen, M. (ed.) High temperature - low pressure metamorphism and deep crustal structures. Geological Survey of Finland, Guide 37, 11-20.

Korsman, K. 1977. Progressive metamorphism of the metapelites in the Rantasalmi-Sulkava area, south-eastern Finland. Geological Survey of Finland, Bulletin 290. 82 p.

Korsman, K., Hölttä, P., Hautala, T. \& Wasenius, P. 1984. Metamorphism as an indicator of evolution and structure of the crust in Eastern Finland. Geological Survey of Finland, Bulletin 328. 40 p.

Korsman, K. \& Kilpeläinen, T. 1986. Relationship between zonal metamorphism and deformation in the Rantasalmi-Sulkava area, southeastern Finland. Geological Survey of Finland, Bulletin 339, 33-42.

Korsman, K., Koistinen, T., Kohonen, M., Wennerström, M., Ekdahl, E., Honkamo, M., Idman, H. \& Pekkala, Y. (eds.) 1997. Suomen kallioperäkartta - Berggrundskarta över Finland - Bedrock map of Finland 1: 1000000. Geological Survey of Finland, Espoo, Finland.

Kretz, R. 1983. Symbols for rock forming minerals. American Mineralogist 68, 277-279.

Lahti, S.I. \& Mäkitie, H. 1990. Jalasjärvi. Geological map of Finland 1: 100 000, Pre-Quaternary rocks, Sheet 2221. Geological Survey of Finland.

Laitakari, A. 1942. Vaasa. Suomen geologinen kartta 1: 400 000, kivilajikartan selitys, lehti B3. Geological Survey of Finland. $66 \mathrm{p}$.

Mäkitie, H. 1990. Progressiivinen metamorfoosi ja deformaatio Seinäjoen-Ilmajoen alueella. Unpublished Lic.Phil. thesis, University of Helsinki, Department of Geology. 80 p. (in Finnish)

Mäkitie, H. \& Lahti, S.I. 1991. Seinäjoen kartta-alueen kallioperä. Summary: Pre-Quaternary rocks of the Seinäjoki map-sheet area. Geological map of Finland $1: 100000$, Explanation to the map of rocks, Sheet 2222. Geological Survey of Finland. 60 p.

Mäkitie, H., Lahti, S.I., Alviola, R. \& Huuskonen, M. 1991. Seinäjoki. Geological map of Finland 1:100 000, PreQuaternary rocks, Sheet 2222. Geological Survey of Finland.

Neuvonen, K.J. 1961. Seinäjoki. Geological map of Finland 1: 100 000, Pre-Quaternary rocks, Sheet 2222. Geological Survey of Finland.

Nurmela, P. 1985. Seinäjoen Pajuluoman alueen pegmatiiteista. Unpublished M.Sc. thesis, University of Helsinki, Department of Geology. 115 p. (in Finnish)

Oivanen, P. 1983. Tinamalmitutkimukset Etelä-Pohjanmaan liuskejakson alueella vuosina 1980-1983. Geological Survey of Finland, unpublished report M 19/2222/ -83/1/10. 26 p. (in Finnish)

Pääkkönen, V. 1966. On the geology and mineralogy of 
the occurence of native antimony at Seinäjoki, Finland. Bulletin de la Commission géologique de Finlande 225. $70 \mathrm{p}$.

Pehrman, G. 1932. Über optisch positiven Cordierit. Acta Academiae Aboensis, Mathematica et physica VI, 11, $1-11$.

Perchuk, L.L. 1989. Intercorrelation of Fe-Mg geothermometer using the Nernst law. Geokhimiya 5, 611-622. (in Russian, translated title)

Powell, C. McA. 1979. A morphological classification of rock cleavage. Tectonophysics 58, 21-34.

Rudnick, R.L. \& Presper, T. 1990. Geochemistry of intermediate- to high-pressure granulites. In: Vielzeuf, D. \& Vidal, P. (eds.) Granulites and Crustal Differentiation. Nato ASI Series C: Mathematical and Physical Sciences. Dordrecht: Kluwer, 523-550.

Salje, E. 1986. Heat capacities and entropies of andalusite and sillimanite: the influence of fibrolitization on the phase diagram of the $\mathrm{Al}_{2} \mathrm{SiO}_{5}$ polymorphs. American Mineralogist 71, 1366-1371.

Schreurs, J. 1985. Prograde metamorphism of metapelites, garnet-biotite thermometry and prograde changes of biotite chemistry in high grade rocks of West Uusimaa, southwest Finland. Lithos 18, 69-80.

Spear, F.S. 1981. An experimental study of hornblende stability and compositional variability in amphibolite. American Journal of Science 281, 697-734.

Spear, F.S. 1993. Metamorphic Phase Equilibria and Pressure-Temperature-Time Paths. Mineralogical Society of
America, Monograph. Washington, DC. 799 p.

Thompson, J.B. 1957. The graphical analysis of mineral assemblages in pelitic schists. American Mineralogist $42,842-858$.

Thompson, J.B. Jr. \& Thompson, A.B. 1976. A model system for mineral facies in pelitic schists. Contributions to Mineralogy and Petrology 58, 243-277.

Tracy, R.J. 1978. High grade metamorphic reactions and partial melting in pelitic schist, west-central Massachusetts. American Journal of Science 278, 150-178.

Vaasjoki, M. \& Sakko, M. 1988. The evolution of the Raahe-Ladoga zone in Finland: isotopic constraints. In: Korsman, K. (ed.) Tectono-metamorphic evolution of the Raahe-Ladoga zone. Geological Survey Finland, Bulletin $343,7-32$.

Väisänen, M., Hölttä, P., Rastas, J., Korja, A. \& Heikkinen, P. 1994. Deformation, metamorphism and deep structure of the crust in the Turku area, southwestern Finland. In: Pajunen, M. (ed.) High temperature - low pressure metamorphism and deep crustal structures. Geological Survey of Finland, Guide 37, 35-41.

Vernon, R.H. 1979. Formation of late sillimanite by hydrogen metasomatism (base-leaching) in some highgrade gneisses. Lithos 12, 143-152.

Zwart, H.J. 1962. On the determination of polymetamorphic mineral associations, and its application to the Bosost area (Central Pyrenee). Geologische Rundschau 52, $38-65$.

Appendix 1. Chemically analysed metapelite samples taken from the Seinäjoki-Ilmajoki area. The analyses are archived in the KALTIE database in the Geological Survey of Finland. The database also includes locations of the samples.

\begin{tabular}{ll}
\hline Metamorphic zone & Samples \\
\hline Andalusite zone & 653-HMM-86, 397-HMM-85, 395-HMM-85, 17M-HMM-84, 657-HMM-86, 680-HMM- \\
& 86, 380A-HMM-85, 380B-HMM-85 \\
Sillimanite-muscovite zone & 811-HMM-86, 783-HMM-86, 651-HMM-86, 760-HMM-86, 130M-PMK-83, 137M- \\
& PMK-83, 782-HMM-86 \\
Sillimanite-K-feldspar zone & 505-HMM-85, 798-HMM-86, 15M-HMM-84, 402-HMM-85 \\
Cordierite-K-feldspar zone & 242-HMM-85, 360-HMM-85, 509-HMM-85, 797-HMM-86, 721-HMM-86, 328-HMM- \\
& 85, 723-HMM-86, 9M-HMM-84, 54P-HMM-86, 53-HMM-86 \\
Garnet-cordierite-K-feldspar & 390S-HMM-85, 512-HMM-85, 340A-HMM-85, 340B-HMM-85, 791-HMM-85, \\
zone & 145A-HMM-82, 145B-HMM-82, 145C-HMM-82, 145D-MM-82, 145E-HMM-82 \\
Contact aureole of the Luopa & 166D-HMM-82, 171E-HMM-82, 171K-HMM-85, 722-HMM-85, 167L-HMM-86 \\
quartz monzonite &
\end{tabular}

